2004s-62

Common and Fundamental Factors in Stock Returns of

Canadian Oil and Gas Companies

\author{
M. Martin Boyer, Didier Filion
}

\begin{tabular}{c}
\hline Série Scientifique \\
Scientific Series
\end{tabular}

Montréal

Décembre 2004

(C) 2004 M. Martin Boyer, Didier Filion. Tous droits réservés. All rights reserved. Reproduction partielle permise avec citation du document source, incluant la notice (C).

Short sections may be quoted without explicit permission, iffull credit, including (C) notice, is given to the source.
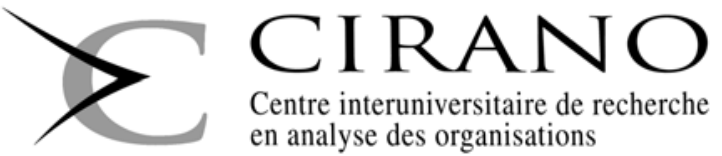

Centre interuniversitaire de recherche en analyse des organisations 


\section{CIRANO}

Le CIRANO est un organisme sans but lucratif constitué en vertu de la Loi des compagnies du Québec. Le financement de son infrastructure et de ses activités de recherche provient des cotisations de ses organisations-membres, d'une subvention d'infrastructure du Ministère du Développement économique et régional et de la Recherche, de même que des subventions et mandats obtenus par ses équipes de recherche.

CIRANO is a private non-profit organization incorporated under the Québec Companies Act. Its infrastructure and research activities are funded through fees paid by member organizations, an infrastructure grant from the Ministère du Développement économique et régional et de la Recherche, and grants and research mandates obtained by its research teams.

PARTENAIRE MAJEUR

$$
\text { Les organisations-partenaires / The Partner Organizations }
$$

. Ministère du Développement économique et régional et de la Recherche [MDERR]

PARTENAIRES

. Alcan inc.

. Axa Canada

. Banque du Canada

. Banque Laurentienne du Canada

. Banque Nationale du Canada

. Banque Royale du Canada

. Bell Canada

. BMO Groupe Financier

. Bombardier

. Bourse de Montréal

. Caisse de dépôt et placement du Québec

. Développement des ressources humaines Canada [DRHC]

. Fédération des caisses Desjardins du Québec

. GazMétro

. Groupe financier Norshield

. Hydro-Québec

. Industrie Canada

. Ministère des Finances du Québec

. Pratt \& Whitney Canada Inc.

. Raymond Chabot Grant Thornton

. Ville de Montréal

. École Polytechnique de Montréal

. HEC Montréal

. Université Concordia

. Université de Montréal

. Université du Québec

. Université du Québec à Montréal

. Université Laval

. Université McGill

. Université de Sherbrooke

ASSOCIE A :

. Institut de Finance Mathématique de Montréal (IFM²)

. Laboratoires universitaires Bell Canada

. Réseau de calcul et de modélisation mathématique $\left[\mathrm{RCM}^{2}\right]$

. Réseau de centres d'excellence MITACS (Les mathématiques des technologies de l'information et des systèmes complexes)

Les cahiers de la série scientifique $(\mathrm{CS})$ visent à rendre accessibles des résultats de recherche effectuée au CIRANO afin de susciter échanges et commentaires. Ces cahiers sont écrits dans le style des publications scientifiques. Les idées et les opinions émises sont sous l'unique responsabilité des auteurs et ne représentent pas nécessairement les positions du CIRANO ou de ses partenaires.

This paper presents research carried out at CIRANO and aims at encouraging discussion and comment. The observations and viewpoints expressed are the sole responsibility of the authors. They do not necessarily represent positions of CIRANO or its partners. 


\title{
Common and Fundamental Factors in Stock Returns of Canadian Oil and Gas Companies*
}

\author{
M. Martin Boyer ${ }^{\dagger}$, Didier Filion
}

\section{Résumé / Abstract}

Le but de cet article est de mesurer ce qui influence le rendement des actions d'entreprises pétrolières et gazières canadiennes. Nous trouvons que le rendement des actions de ces entreprises énergétiques est influencé positivement par le rendement du marché canadien dans son ensemble, par une appréciation du prix du pétrole et du gaz naturel, par une croissance dans les flux monétaires discrétionnaires de l'entreprise, par la quantité de réserves prouvées de l'entreprise. Nous trouvons également que le volume de production et une dépréciation du dollar canadien par rapport à la devise américaine réduit sensiblement le rendement des titres énergétiques, ce qui va à l'encontre de notre hypothèse initiale. L'impact du taux de change est encore plus marqué pour les producteurs indépendants que pour les entreprises intégrées. En dernier lieu, nous montrons que le marché a subi une cassure significative entre les années 19951998 et 2000-2002, spécialement pour ce qui est de l'impact du taux de change, du rendement de marché et du pris du gaz naturel.

Mots clés : rendement des actions, analyse de données transversales, industrie pétrolière et gazière.

In this paper, we assess the determinants of Canadian oil and gas stocks returns. We find that the stock return of Canadian energy stock is positively associated with returns on the Canadian stock market, appreciations of crude oil and natural gas prices, growth in internal cash flows and proven reserves, and negatively with interest rates. Surprisingly, however, production volume and a weakening of the Canadian dollar against the U.S. dollar have a negative impact. This latter impact is more pronounced for oil producers than for integrated energy companies. Finally, we find that the influence of the exchange rate, the market return and prices of natural gas on Canadian oil and gas stocks changes significantly over the years 1995-1998 and 2000-2002.

Keywords: stock return valuation, panel data analysis, oil and gas industry.

\footnotetext{
* We are grateful for comments received by Kodjovi Assoé. This research was funded by the Social Science and Humanities Research Council of Canada and by the Fonds pour la formation de chercheurs et d'aide à la recherche du Québec. The continuing financial support of Cirano is also appreciated.

${ }^{\dagger}$ Corresponding author. M. Martin Boyer is in the Finance Department at HEC Montréal, Université de Montréal, 3000 Chemin de la Côte-Ste-Catherine, Montréal, QC H3T 2A7; 514-340-6704; martin.boyer@hec.ca. + Didier Filion is at the Caisse de Dépôt et de Placement du Québec; filion@cdpq.qc.ca.
} 


\section{Introduction}

The valuation of assets is a subject richly documented and largely debated. While some try to find common factors to a majority of stocks or to specific stocks (see Keim and Stambaugh, 1986, Fama and French, 1989, 1993, Chen, 1991), academics have shown how difficult and complex could be the construction of a model to price stocks. The influence of factors (macroeconomics, accounting and other) depends on the timeframe, the measures employed, the database, or simply on the operations of the corporation. In particular, different industries react to different factors: A sudden increase in commodity prices should lead to an increase in the market value of firms producing the commodity, but it should also lead to a decrease in the value of net buyers.

Within this framework, the problematic surrounding the valuation of assets is largely a matter of perspective. The goal for researchers is to devise a more accurate model so that we understand better the determinants of stock returns. In this paper, we evaluate and quantify the variations of Canadian oil and gas stocks in light of common (i.e., macroeconomic) and fundamental determinants.

As Sadorsky (2002) reports, "the idea that macroeconomic variables can help to explain excess returns in equity and bond markets has recently been extended to commodity futures markets (page 540)." A particularity of the oil and gas firms is that their value is driven by commodity prices. It is thus worthwhile to study the impact of macroeconomic factors on corporations operating in that sector.

The purpose of this research is four-fold.

1- We measure the sensitivity of Canadian oil and gas stock returns to five common factors: Interest rates, the Canadian exchange rate with the U.S. dollar, the market return, oil prices, and natural gas prices;

2- We estimate the impact on these stock returns of five fundamental determinants: Fluctuation of proven reserves, volumes of production, debt level, operational cash flows, and drilling success;

3- We analyze the influence of different price environments and operational activities on our valuation models to identify structural changes associated with large shifts in prices of natural gas and crude oil; 
4- Finally, we analyze whether the same results hold for integrated energy companies $^{2}$ compared to independent producers; we do the same exercise for firms producing mainly crude oil and for firms focusing on natural gas.

Our main contributions to the literature rests on our innovation of including natural gas prices and fundamental factors specific to the industry in a valuation model for oil and gas stock returns. Furthermore, we innovate by examining the differences between producers and integrated firms, and among companies concentrating their effort on crude oil or natural gas.

We also improve previous studies related the energy sector by using a sample of companies instead of a sub-index (Sadorsky, 2001; Aleisa and al., 2003). Our sample includes firms with different ownership structures, various sizes and several average daily volumes of transactions. This compares advantageously to sub-indexes where many enterprises are included but are restricted on certain aspects, notably with regard to the liquidity of their shares.

The structure of our paper is as follow. First, we look at the literature concerning the valuation of Canadian stocks, pertinent industries and the energy sector. Second, we explain the methodology, our hypotheses and the determinants. The data we use to test our hypotheses is presented in Section 4 . Section 5 focuses on the regression results and discusses the implications. Finally we conclude the paper in Section 6.

\section{Literature}

Using a capital asset pricing model (CAPM) approach, early research by Morin (1980) on the Canadian market shows, compared to American stocks, that market returns do not have an important explanatory power in Canada. Morin (1980) attribute this result to the less diversified Canadian economy and to a greater focus on natural resources. These two factors explain why Canadian stock returns are more sensible to fundamental factors and less sensible to market factors. In this sense, Jorion and Swartz (1986), using a

\footnotetext{
${ }^{2}$ Integrated energy companies are implicated in downstream activities (marketing, refinery, distribution) as well as upstream operations (exploration, development, production). Producers concentrate their effort on upstream activities.
} 
North-American CAPM, point out that it is impossible to justify the behavior of Canadian stocks only with North-American market returns.

Consequently, academics looked at the problem using other methods. Kryzanowski and To (1983), Hughes (1984), Abeysekera and Mahajan (1987), Mittoo (1992) and Koutoulas and Kryzanowski (1994) use multifactor models to understand the return of Canadian stocks. The main common conclusion of these authors is that, because only few stocks are correlated to the same determinants, it takes many factors to explain the entire return of Canadian stocks. ${ }^{3}$ However, Abeysekera and Mahajan (1987) as well as Kryzanowski and To (1983) also note that a model with four or five variables might be enough to get a notable explanatory power.

As for the determinants which have an effect on Canadian stocks, Koutoulas and Kryzanowski (1994) find that the pure domestic components of the interest rate structure, lagged industrial production, pure international components of the differential in the Canada/U.S. leading indicators, and the interest rate of Euro deposits have a significant influence on Canadian assets. On the other hand, Mittoo (1992) notes that only the 3-month T-bill interest rate explains the return of Canadian stocks.

While the previous literature has looked at the valuation problematic on a geographic basis, academics have also studied the question from an industrial outlook. In particular, studies concerning the Australian gold industry and the Canadian pulp \& paper and forest industry have come to our attention.

For example, Faff and Chan (1998) regress, from 1979 to 1992, the Australian gold index on the Australian market return, gold prices, the \$AUS/\$US exchange rate, and on different interest rates. They observe that the market return and gold prices are the only variables that have a significant influence on Australian gold stocks. The authors also find a market beta superior to one so that the Australian gold sector appears riskier than the market. This result is contrary to the findings of Chua and al. (1990) who find a beta smaller than one and to McDonald and Solnick (1977) who find a negative correlation between the S\&P 500 and gold prices over a 27 years period.

\footnotetext{
${ }^{3}$ Hughes (1984) finds 12 factors, Kryzanowski and To (1983) find 18 to 20 factors.
} 
Regarding the Canadian pulp \& paper and forest industry, Henriques and Sadorsky (2001) study the problematic surrounding the valuation with a model that includes the Canadian market return, the Canadian industrial materials spot price commodity index, the exchange rate of the Canadian dollar against 10 currencies, and the term premium. They find that only three determinants have a significant impact on the stock returns of Canadian paper and forest firms. The market return has an important explanatory power on the stocks and they react pro-cyclically. In addition, an increase in commodity prices leads to an appreciation of Canadian paper and forest share prices. As for the exchange rate, a depreciation of the Canadian dollar is beneficial.

In the energy industry literature Kavussanos and Marcoulis (1997) study the impact of the market return and the Fama and French (1992) factors on the profitability of oil refining firms. Their main conclusion is that the market return (S\&P 500) has the largest impact the share price of refineries. The market value of equity (ME) and the assets value relative to the market value of equity $(\mathrm{A} / \mathrm{ME})$ have small positive influence, while the assets value relative to the book value $(A / B E)$ has a small impact. These results are consequent with the theory.

Another paper looking at American oil and gas companies brings to light two important details. Firstly, using the Johansen (1988) co-integration test, Aleisa and al. (2003) show that price fluctuations of West Texas Intermediate (WTI) barrel 1-month to 4-month futures explain share price movements of firms operating in exploration, refinery and marketing of oil. In fact, they note that the degree of co-integration varies between crude oil prices and the firm type. Firms included in the S\&P Oil Composite Index, the S\&P Oil Domestic Integrated Index and the S\&P Oil International Integrated Index have a stronger link to crude oil prices than firms included in the S\&P Oil and Gas Exploration Index or the S\&P Oil and Gas Refining and Marketing Index. Secondly, Aleisa and al. (2003) find that the five sub-indices are not co-integrated.

A final study acts as a basis for our paper. Sadorsky (2001) deepens the analysis of the Canadian oil and gas industry by using a model where the TSE Oil and Gas Index is explained by the Canadian market return, crude oil prices, the Canada-US exchange rate and the short term Canadian interest rates. He finds that the four factors have an 
influence on Canadian energy stocks, although the first two have a much larger impact. This result comes in opposition with Ferson and Harvey (1991) who state that real interest rates and market return are the most important determinants in explaining the return of American petroleum shares. Sadorsky (2001) also observes that crude oil prices and market return have a positive effect on stock prices whereas a depreciation of the Canadian dollar and an increase of interest rates have a negative effect on Canadian oil and gas stocks.

\section{Methodology and hypothesis construction}

The methodology we use is based on the multifactor models used by Jorion (1990), Khoo (1994), Faff and Chan (1998), Faff and Brailsford (1999), Henriques and Sadorsky (2001) and Sadorsky (2001). We suppose that the variation of Canadian oil and gas stocks prices is associated with movements of common and fundamental determinants. We thus quantify the risk that these factors represent.

Our first step is to use the five common factors as explanatory variables for each firm's stock return. We employ a generalized least squared (GLS) cross-sectional time series linear model. This procedure controls for heteroskedasticity and autocorrelation, present in the data. ${ }^{4}$ Mathematically, our first model takes the following form:

$$
r_{i, t}=\alpha+\beta_{i r} r_{i r, t}+\beta_{e r} r_{e r, t}+\beta_{m} r_{m, t}+\beta_{\text {oil }} r_{o i l, t}+\beta_{\text {gas }} r_{\text {gas }, t}+\varepsilon_{t}
$$

Our dependent variable $\left(r_{i, t}\right)$ is the excess return of each stock over the 1-month T-bill rate. The independent variables are the interest rate return $\left(r_{i r, t}\right)$, the exchange rate return $\left(r_{e r, t}\right)$, the market excess return over the 1-month T-bill rate $\left(r_{m, t}\right)$, the crude oil price return $\left(r_{\text {oil,t }}\right)$ and the natural gas price return $\left(r_{\text {gas,t }}\right)$. Finally, $\alpha$ is the constant and $\varepsilon_{t}$ are the residuals. All returns are on a quarterly basis and the period under study covers March 1995 to September 2002.

To compare the behavior of integrated companies and producers, we form two portfolios: The first includes the 99 producers and the second includes the 6 integrated firms. We then calculate the five common factor betas for each portfolio. The appropriate

\footnotetext{
${ }^{4}$ Although technically we should have employed Zellner's seemingly unrelated regression model to compare the two groups, we were unable to do so because we have a panel data set so that a change in the matrix form would have eliminated all explanatory power and no conclusion would have been reached.
} 
econometric model is thus a GLS cross-sectional time series linear model with dummy variables. Equation (2) defines this process:

$$
\begin{aligned}
& r_{i, t}=\alpha+\beta_{1 i r} r_{i r, t}+\beta_{1 e r} r_{e r, t}+\beta_{1 m} r_{m, t}+\beta_{1 \text { oil }} r_{\text {oil }, t}+\beta_{1 \text { gas }} r_{\text {gas }, t}+ \\
& D_{1} \beta_{2 i r} r_{i r, t}+D_{2} \beta_{2 e r} r_{e r, t}+D_{3} \beta_{2 m} r_{m, t}+D_{4} \beta_{2 \text { oil }} r_{\text {oil }, t}+D_{5} \beta_{2 \text { gas }} r_{\text {gas }, t}+\varepsilon_{t}
\end{aligned}
$$

The difference between equations (2) and (1) is the inclusion in equation (2) of dummy variables $\left(D_{1}, D_{2}, D_{3}, D_{4}, D_{5}\right)$ equal to 1 when the firm is integrated and 0 when the firm is an independent producer. The different $\beta_{1}$ are the variable coefficients related to the entire sample (producers and integrated) while the $\beta_{2}$ are unique to integrated firms. As a result the coefficient for each common variable is given by the different $\beta_{1}$ in the case of producers, and by $\beta_{1}+\beta_{2}$ in the case of integrated.

Figure 1: The evolution of crude oil and natural gas prices (\$US)

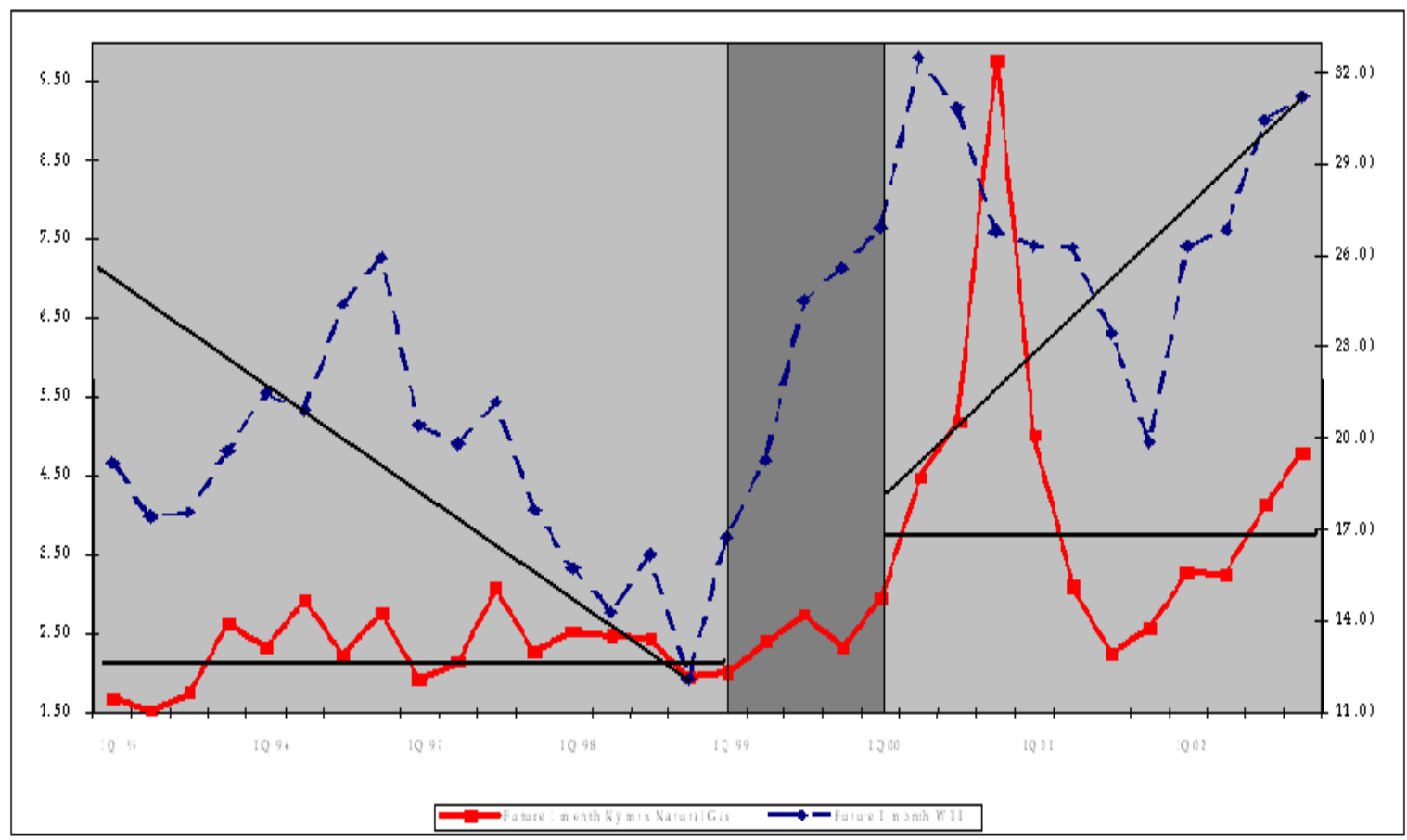

Source : Bloomberg

We use this procedure two more times; first to study the difference between firms producing mainly natural gas and those focusing on crude oil, and second to test if a change in the pricing environment had an impact on the coefficients. Regarding the price environment, we compare a period of decreasing crude oil prices and low natural gas 
prices (1995-1998) with a period of increasing crude oil prices and high natural gas prices (2000-2002). The year of 1999 is considered as a period of transition. We thus provide a test for the presence of a structural change evident in Figure 1.

Finally, we modify model (1) by adding five fundamental factors to assess the influence of financial and operational factors: the variation in drilling success $\left(r_{\text {dri, }}, t-1\right)$, the variation in cash flows $\left(r_{c f, i, t-1}\right)$, the variation in proven reserves $\left(r_{r e s, i, t-1}\right)$, the variation in production volume $\left(r_{\text {prod,i,t-1 }}\right)$, and the variation in debt $\left(r_{\text {dette, }, \mathrm{t}-1-1}\right)$. The following equation is thus tested:

$$
\begin{aligned}
& r_{i, t}=\alpha+\beta_{i r} r_{i r, t}+\beta_{e r} r_{e r, t}+\beta_{m} r_{m, t}+\beta_{\text {oil }} r_{\text {oil }, t}+\beta_{g a s} r_{g a s, t}+\beta_{d r i} r_{d r i, i, t-1} \\
& +\beta_{c f} r_{c f, i, t-1}+D_{1} \beta_{r e s} r_{r e s, i, t-1}+\beta_{\text {prod }} r_{p r o d}, i, t-1+\beta_{\text {debt }} r_{d e b t, i, t-1}+\varepsilon_{t}
\end{aligned}
$$

Again our dependent variable, $r_{i, t}$, is the excess return of each stock over the 1-month Tbill rate. The $r_{i r}, r_{e r}, r_{m}, r_{\text {oil }}$ and $r_{\text {gas }}$ are the returns related to the five common factors previously defined. All returns are on a quarterly basis, except for the variation of proven reserves. As a result, we let $D_{1}$ be a dummy variable equal to 0 in the first three quarters and equal to 1 in the fourth. The timeframe is from March 1995 to September 2002.

\subsection{Common determinants}

One important characteristic of the Canadian oil and gas industry is that it is a net exporter. According to the International Energy Agency (www.iea.org), Canadian exports of crude oil, natural gas and refined products were respectively 1.6, 27.7 and 1.9 times more important than imports in 2001. These exports were mainly directed to the United States. On the import side Canadian energy firms import machinery and borrow from abroad (see Sadorsky, 2001). On top of this, international operations are important for some firms: Canadian Natural Resource in the North Sea and the Ivory Coast, Nexen in the Gulf of Mexico, and Talisman Energy in Qatar and Algeria.

Hence, it is clear that Canadian oil and gas stocks are exposed to currency risks so that the value of the Canadian dollar has an impact on the bottom line of almost every firm in our sample. In particular, in Petro-Canada's 2003 Annual Report, we can read: "Economic factors influencing Petro-Canada's upstream financial performance include crude oil and natural gas prices, and foreign exchange rates, particularly the Canadian 
dollar/U.S. dollar rate." The inclusion of the \$CAN/\$US exchange rate in our model is consistent with this situation.

Crude oil and natural gas price fluctuations are another common risk factor for firms in the industry. Similarly to the exchange rate, they influence decision at all management and operational levels. Price fluctuations directly affect revenues, profits, investments and cash flows. They are thus essential to include in any profitability assessment.

Another attribute of the industry is the scale of the investments necessary to operate. The capital needed to purchase, develop and operate properties is enormous. Moreover, the normal business and equipment maintenance costs are large, particularly for oil sands and offshore activities. Oil and gas companies also need to invest to renew and find reserves to meet their growth and cash flow objectives. This capital intensity has ubiquitous consequences on the firms' financial structure in the sense that external financing is unavoidable. The use of debt is thus widely spread so that interest rates variations likely represent an important risk factor.

Finally, based on the theory developed by Sharpe (1964) and Merton (1973) and with regard to the previously cited literature, the return on the Canadian stock market should have an impact on Canadian oil and gas stock returns. By measuring the sensitivity of oil and gas stock prices to this factor, we will be able to judge whether the sector riskier than the overall stock market, and whether Canadian oil and gas stock returns are procyclical or counter-cyclical.

A priori we expect that the market return, crude oil prices and natural gas prices should have a positive impact on oil and gas stock returns. We expect that the level of interest rates should have a negative impact on stock price returns. As for the exchange rate, we have no prior regarding its impact because Canada is a net exporter of oil and gas, but a net importer of oil and gas machinery.

With regards to commodities prices, we use the quarterly returns on the West Texas Intermediate (WTI) barrel 1-month futures and NYMEX Natural Gas 1-month futures. We chose futures prices because spot prices are more affected by temporary random noise 
(Sadorsky, 2001). Moreover, Aleisa and al. (2003) highlight the co-integration of U.S. energy stocks with 1-month futures.

The reasons we use the prices of the West Texas Intermediate (WTI) and of the NYMEX Natural Gas are three-fold. First, they are most widely used indices in North-America. Even Canadian indices are priced according to a spread with the two benchmarks. Second, when firms use hedging instruments, the vast majority uses futures, forwards and other derivatives contracts based on the WTI and the Nymex Natural Gas prices. Thirdly, by using these two U.S. dollar denominated prices, we are able to identify and isolate the impact of a variation in the exchange rate independently of a variation in commodity prices. If we were to use a price in Canadian dollars, a change in the value of the index could only be the result of a change in the \$CAN/\$US exchange rate instead of a variation in commodity prices. The effect of the exchange rate would therefore be impossible to isolate if we use an index stated in Canadian dollars.

\subsection{Fundamental determinants}

Previous work has shown that, irrespective of the Modigliani-Miller paradigm, debt has an impact on a firm's value as shown in the extensive literature of Myers (1977), Jensen (1986) and Stulz (1990). In particular, Fama and French (1992) and Kavussanos and Marcoulis (1997) showed that leverage, whether measured using accounting or market values, has a significant impact on stock prices. Although no particular relationship between stock price returns and debt level is expected, it is nonetheless essential to control for firm debt in our regression model, given the extensive related literature.

We also add other factors in equation (3) that are particular to the oil and gas industry cycle. As described in the Canadian Security Handbook, this cycle is divided into four segments: 1-Acquisition of undeveloped lands and exploration; 2-Resources and proven reserves estimation; 3-Production; 4-Return on investment. We want to measure the risk associated with each stage of the cycle using respectively drilling success, proven reserves, production volume and operational cash flows; all of which are reported in the firms' quarterly and annual reports. Our presumption is that these measures are used by investors as a signal of a firm's operational and financial health. A firm's value is then determined by its number of production-years left and on its growth potential. 
Because these four risk factors are normally priced by investors, we believe that they are pertinent in a valuation model. We thus anticipate that drilling success, proven reserves, production volume and operational cash flows should have a positive impact on oil and gas stock price returns.

Regarding our measure of the variation of drilling success, $r_{\text {dri }}$ measures, drilling success is calculated as the proportion of completed wells (i.e., wells in operations) as a fraction of the total number of wells drilled (including dry and abandoned wells). $r_{r e s}$ is thus measured in connection with the firm's level of production to consider that a firm might increase reserves but not growth if production increases faster than its reserves. We use proven reserves ${ }^{5}$ because the measure is more reliable than probable reserves.

\section{Data}

Our sample consists of 105 Canadian oil and gas corporations, of which 99 are pure play producers and 6 are integrated firms. The sample does not include income trusts. All companies are Canadians and their shares are traded on a Canadian exchange. Table A1 in the appendix lists all the companies included in our study. The number of observations is limited due to the limited availability of historical operational data. Furthermore, a wave of consolidation in the industry during the time period under study contributed to a reduction in the total number of observations.

We found quarterly returns in Datastream and Bloomberg and are in excess of the 1month Canadian T-bill rate (Ferson and Harvey, 1991; Sadorsky, 2001). The interest rate measure is calculated as the quarterly variation of the term premium described by Fama and French (1992). Table 1 presents a summary of how all the independent variables were calculated.

\footnotetext{
5 Proven reserves are considered recoverable under current technology and existing economic and environmental conditions, from reservoirs that are evaluated on known drilling, geological, geophysical and engineering data. In other words, proven reserves are recoverable given the current technology, but they are not because of financial and/or cost constraints. Proven reserves are the next reserves to be developed when the firm has sufficient cash flows to initiate their development.
} 


\section{Table 1: measure of independent variables}

\begin{tabular}{|c|c|c|}
\hline Variable & Source & Measure (in \%) ${ }^{6,7}$ \\
\hline Market return & Bloomberg & $r_{m}=T S E 300$ Quarterly return -1 month Canadian T-bill rate \\
\hline Interest rate & Datastream & $\begin{array}{l}r_{\text {it }}=[((\text { Rate premium between the yield on } 10 \text { years Canadian corporate } \\
\text { Bonds and the yield on } 10 \text { years Canadian Treasury Bonds })-90 \text {-day } \\
\text { commercial paper rate }) /(\text { Rate premium between the yield on } 10 \text { years } \\
\text { Canadian corporate Bonds and the yield on } 10 \text { years Canadian } \\
\left.\text { Government Bonds })-90 \text {-day commercial paper rate })_{t-1}\right]-1\end{array}$ \\
\hline Exchange rate & Bloomberg & $r_{\text {er }}=\left((\text { Exchange rate } \$ C A N / \$ U S)_{t} /(\text { Exchange rate } \$ C A N / \$ U S)_{t-1}\right)-1$ \\
\hline Crude oil price $^{8}$ & Bloomberg & $\begin{array}{l}r_{\text {oil }}=((\text { Price of the } W T I \text { barrel in } \$ U S) /(\text { Price of the } W T I \text { barrel in } \$ \cup S) t- \\
\text { 1)-1 }\end{array}$ \\
\hline Natural gas price & Bloomberg & $\begin{array}{l}r_{\text {gas }}=\left((\text { Price of NYMEX Natural Gas in \$US })_{t} /(\text { Price of NYMEX Natural }\right. \\
\left.\text { Gas in } \$ \text { US })_{t-1}\right)-1\end{array}$ \\
\hline Debt & $\begin{array}{l}\text { Canoil from Woodside } \\
\text { Research }\end{array}$ & $r_{\text {debt }}=\left((\right.$ Long term debt in \$CAN $\left.) t(\text { Long term debt in \$CAN })_{\mathrm{t}-1}\right)-1$ \\
\hline Production & $\begin{array}{l}\text { Canoil from Woodside } \\
\text { Research }\end{array}$ & $r_{\text {prod }}=\left((\right.$ Total production in boe $\left.) t(\text { Total production in boe })_{t-1}\right)-1$ \\
\hline Cash flows & $\begin{array}{l}\text { Canoil from Woodside } \\
\text { Research }\end{array}$ & $\begin{array}{l}r_{\text {cf }}=\left((\text { Operational cash flows in } \$ C A N)_{t} /(\text { Operational cash flows in }\right. \\
\left.\$ C A N)_{t-1}\right)-1\end{array}$ \\
\hline Proven reserves & $\begin{array}{l}\text { Canoil from Woodside } \\
\text { Research }\end{array}$ & $\begin{array}{l}r_{\text {res }}=\left((\text { Total proven reserves in boe/Total production in boe })_{t} /(\text { Total }\right. \\
\left.\text { proven reserves in boe/Total production in boe })_{t-1}\right)-1\end{array}$ \\
\hline Drilling success & $\begin{array}{l}\text { Canoil from Woodside } \\
\text { Research }\end{array}$ & $\begin{array}{l}r_{\text {dri }}=((\text { Completed oil and gas wells drilled/Total oil and gas wells } \\
\text { drilled })_{t} /(\text { Completed oil and gas wells drilled/Total oil and gas wells } \\
\left.\text { drilled })_{t-1}\right)-1\end{array}$ \\
\hline
\end{tabular}

Table 2 presents the summary statistics for each explanatory variable.

\section{Table 2: descriptive statistics}

\begin{tabular}{|c|c|c|c|c|}
\hline Variable & Mean (\%) & Median (\%) & Stand. dev. (\%) & t-statistic \\
\hline $\mathbf{r}_{\mathrm{i}}$ & 3.9456 & -1.6537 & 46.2530 & $3.9701^{* * *}$ \\
\hline $\mathbf{r}_{\mathrm{ii}}$ & 4.3707 & 0.8204 & 37.3105 & $1.4725^{\star}$ \\
\hline$r_{p i}$ & 3.9121 & -1.9250 & 46.8918 & $3.7385^{\star * *}$ \\
\hline$r_{m}$ & -2.6137 & -2.2850 & 10.2519 & $-1.3964^{*}$ \\
\hline$r_{\mathrm{er}}$ & 0.4503 & 0.2350 & 2.4701 & 0.9986 \\
\hline$r_{\text {ir }}$ & -1.7819 & -4.5940 & 31.3744 & -0.3111 \\
\hline$r_{\text {oil }}$ & 2.6673 & 1.4475 & 15.2337 & 0.9431 \\
\hline$r_{\text {gas }}$ & 7.1436 & 11.2275 & 29.4268 & 1.3075 \\
\hline $\mathbf{r}_{\mathrm{dri}}$ & 2.6578 & 0.3676 & 25.7921 & $3.5682^{\star \star \star}$ \\
\hline $\mathbf{r}_{\text {res }}$ & 2.1982 & -2.0284 & 49.0219 & 0.8625 \\
\hline$r_{\text {debt }}$ & 111.2071 & 3.7858 & 2791.9829 & $1.6485^{\star *}$ \\
\hline$r_{\text {prod }}$ & 35.7430 & 48.1996 & 70.9173 & $20.5967^{* * *}$ \\
\hline$r_{c f}$ & 56.2296 & 49.1920 & 536.7876 & $4.7080^{* * *}$ \\
\hline
\end{tabular}

Note: * Significant variable at $10 \% ;{ }^{* *}$ Significant variable at $5 \%$; ${ }^{* * *}$ Significant variable at $1 \%$.

\footnotetext{
${ }^{6}$ All measures are on a quarterly basis, except for proven reserves that are on a yearly basis.

${ }^{7}$ The notation "boe" refers to barrel of oil equivalent. This means that each ten millions cubic feet (mcf) of natural gas is converted into one barrel of crude oil (Kairkkainen, 1997).

${ }^{8}$ To be coherent with the industry that does not distinct them, we use the term "crude oil" to includes both natural gas liquids (NGL) and crude oil per se. The reason is that NGL volumes are small and its price fluctuates in the same range are crude oil prices.
} 
Table 3 presents the correlation matrix between the different factors

Table 3: correlation matrix

\begin{tabular}{|c|c|c|c|c|c|c|c|c|c|c|c|}
\hline & $r_{i}$ & $r_{m}$ & $r_{\text {er }}$ & $r_{i r}$ & $r_{\text {oil }}$ & $r_{\text {gas }}$ & $\mathbf{r}_{\text {dri }}$ & $\mathbf{r}_{\text {res }}$ & $\mathbf{r}_{\text {debt }}$ & $r_{\text {prod }}$ & $r_{c f}$ \\
\hline$r_{i}$ & 1.000 & 0.058 & -0.101 & 0.026 & 0.216 & 0.145 & 0.039 & 0.026 & 0.031 & -0.074 & 0.072 \\
\hline$r_{m}$ & & 1.000 & -0.546 & 0.123 & -0.014 & 0.109 & 0.024 & 0.0435 & 0.0245 & -0.128 & -0.048 \\
\hline$r_{\text {er }}$ & & & 1.000 & -0.131 & -0.271 & -0.183 & 0.031 & -0.002 & 0.003 & 0.209 & 0.022 \\
\hline$r_{\text {ir }}$ & & & & 1.000 & 0.161 & 0.073 & -0.018 & -0.032 & 0.017 & -0.064 & -0.152 \\
\hline$r_{\text {oil }}$ & & & & & 1.000 & 0.241 & 0.018 & -0.113 & -0.005 & 0.017 & 0.001 \\
\hline$r_{\text {gas }}$ & & & & & & 1.000 & 0.006 & -0.013 & 0.016 & -0.102 & 0.208 \\
\hline$r_{\text {dri }}$ & & & & & & & 1.000 & -0.026 & 0.030 & 0.042 & -0.028 \\
\hline$r_{\text {res }}$ & & & & & & & & 1.000 & -0.023 & -0.018 & -0.332 \\
\hline$r_{\text {debt }}$ & & & & & & & & & 1.000 & 0.001 & -0.024 \\
\hline $\mathbf{r}_{\text {prod }}$ & & & & & & & & & & 1.000 & -0.195 \\
\hline$r_{\mathrm{cf}}$ & & & & & & & & & & & 1.000 \\
\hline
\end{tabular}

We see in Table 3 that crude oil prices return and natural gas prices return are positively correlated. The exchange rate is negatively correlated with these two variables. A similar negative correlation between the $\$ C A N / \$ U S$ exchange rate and crude oil price returns was established by Lafrance and Van Norden (1995) who argue that an increase of energy prices in Canada leads to a real depreciation of the Canadian dollar. In accordance with Jones and Kaul (1996) and Sadorsky (1999), who find that the Canadian market reacts negatively to an increase of oil prices, we find a negative correlation between operational cash flows, volume of production, market returns and oil prices. The correlation coefficients are sufficiently small to suggest that multi-collinearity should not present a major problem.

We present in Table 4 more summary statistics to show the considerable difference between integrated firms and producers. Integrated firms are larger on average, have greater volumes of production, more debt, greater proven reserves and higher operational cash flows. Moreover, their drilling success is greater than the producers'. It is also important to note that, due to the composition of the sample, the subgroup of producers presents notable standard deviations. Indeed, the sub-group of producers include junior firms such as Purcell Energy (quarterly revenues of 20 millions \$CAN) as well as large firms such as Canadian Natural Resources (quarterly revenues of 2 billions $\$ C A N)$ that are as large as some integrated companies. 
Table 4: summary of the sample and the explanatory variables

\begin{tabular}{|c|c|c|c|}
\hline Observations & Mean & Median & Standard deviation \\
\hline Exchange rate (\$CAN/\$US) & 1.46 & 1.47 & 0.08 \\
\hline Crude oil price (\$US/barrel) & 22.53 & 21.47 & 5.33 \\
\hline Natural gas price (\$US/mcf) & 2.97 & 2.52 & 1.55 \\
\hline Interest rate premium (\%) & 2.54 & 2.16 & 1.29 \\
\hline $\begin{array}{l}\text { Quarterly volume of crude oil } \\
\text { production (boe): } \\
\text { - integrated (6) } \\
\text { - producers (99) }\end{array}$ & $\begin{array}{c}29538204 \\
4529324\end{array}$ & $\begin{array}{c}23495000 \\
819000\end{array}$ & $\begin{array}{l}22513647 \\
10621184\end{array}$ \\
\hline $\begin{array}{l}\text { Quarterly volume of natural gas } \\
\text { production (boe): } \\
\begin{aligned} \text { - integrated (6) } \\
\text { - producers (99) }\end{aligned}\end{array}$ & $\begin{array}{c}11248088 \\
3034560\end{array}$ & $\begin{array}{c}10027400 \\
723844\end{array}$ & $\begin{array}{l}6583200 \\
5853480\end{array}$ \\
\hline $\begin{array}{l}\text { Drilling success (\%): } \\
\begin{aligned} & \text { - integrated (6) } \\
& \text { - producers }(99)\end{aligned}\end{array}$ & $\begin{array}{l}86.85 \\
76.77\end{array}$ & $\begin{array}{l}90.63 \\
77.97\end{array}$ & $\begin{array}{l}14.44 \\
13.45\end{array}$ \\
\hline $\begin{array}{l}\text { Proved reserves (boe): } \\
\begin{aligned} & \text { - integrated (6) } \\
& \text { - producers (99) }\end{aligned}\end{array}$ & $\begin{array}{l}811005816 \\
114160744\end{array}$ & $\begin{array}{c}628900000 \\
23202300\end{array}$ & $\begin{array}{l}620326495 \\
225014926\end{array}$ \\
\hline $\begin{array}{l}\text { Operational cash flows }(\$ C) \text { : } \\
\qquad \begin{aligned} \text { - integrated }(6) \\
\text { - producers }(99)\end{aligned}\end{array}$ & $\begin{array}{c}565205000 \\
96602546\end{array}$ & $\begin{array}{c}459000000 \\
17150000\end{array}$ & $\begin{array}{l}467708000 \\
256169378\end{array}$ \\
\hline $\begin{array}{l}\text { Long term debt }(\$ C) \\
\begin{aligned} & \text { - integrated }(6) \\
& \text { - producers }(99)\end{aligned}\end{array}$ & $\begin{array}{c}1082719073 \\
253166139\end{array}$ & $\begin{array}{c}1034500000 \\
48253500\end{array}$ & $\begin{array}{l}824669550 \\
589422369\end{array}$ \\
\hline
\end{tabular}

\section{Regression results and return factor analysis}

\subsection{Common factors analysis}

Table 5 presents the regression results for the common multifactor model presented in equation (1). At first glance, we note that all beta coefficients are significant at the $1 \%$ level or better, and support all our hypotheses. As such, we find that the market return, the crude oil price and the natural gas price have a positive impact on oil and gas stock returns, whereas interest and exchange rates have a negative influence. With the exception of natural gas, our results confirm those of Sadorsky (2001).

Interestingly, crude oil price returns had a greater impact on the stock market return of Canadian oil and gas companies than natural gas price returns. We offer two possible explanations. First, since the production of crude oil is on average greater than the production of natural gas, crude oil prices should have a more important impact on the revenues and the profits of Canadian energy firms (and on their stock price) than natural gas prices. Second, according to Haushalter (2000), energy firms are more likely to hedge against the volatility of natural gas prices than the volatility of oil prices. It is thus logical to find $\beta_{\text {gas }}<\beta_{\text {oil }}$ if firms hedge more their exposure to natural gas. 


\section{Table 5: Regressions of the five common factors on the complete sample}

Results using the following equation:

$$
r_{i, t}=\alpha+\beta_{i r} r_{i r, t}+\beta_{e r} r_{e r, t}+\beta_{m} r_{m, t}+\beta_{\text {oil }} r_{o i l, t}+\beta_{\text {gas }} r_{g a s, t}+\varepsilon_{t}
$$

where $r_{i, t}$ is the excess return of each stock on the 1-month T-bill rate, $\alpha$ is the constant, $r_{i r, t}$ is the interest rate return, $r_{\text {er, }}$ is the exchange rate return, $r_{m, t}$ is the market excess return on the 1-month T-bill rate, $r_{\text {oilt, }}$ is the crude oil price return, $r_{\text {gas }, t}$ is the natural gas price return and $\varepsilon_{\mathrm{t}}$ are residuals. All returns are on a quarterly basis and the timeframe is from March 1995 to September 2002. The econometric model is the GLS-Panel.

\begin{tabular}{|c|c|c|c|c|c|c|}
\hline Variable & Const. & $\beta_{m}$ & $\beta_{\text {er }}$ & $\beta_{\text {ir }}$ & $\beta_{\text {oil }}$ & $\beta_{\text {gas }}$ \\
\hline $\begin{array}{l}\text { Coefficient } \\
\text { (Stand. dev.) }\end{array}$ & $\begin{array}{c}2.588^{* * *} \\
(0.341)\end{array}$ & $\begin{array}{c}0.137^{* * *} \\
(0.039)\end{array}$ & $\begin{array}{c}-0.865^{\star * *} \\
(0.126)\end{array}$ & $\begin{array}{c}-0.053^{* * *} \\
(0.014)\end{array}$ & $\begin{array}{c}0.257^{* * *} \\
(0.024)\end{array}$ & $\begin{array}{c}0.113^{* * *} \\
(0.009)\end{array}$ \\
\hline $\begin{array}{ll}\text { Observations } & \\
\text { Panels } & =\end{array}$ & $\begin{array}{c}2166 \\
105\end{array}$ & $\begin{array}{ll}\text { Observations } & \text { min. }= \\
\text { Per panel } & \text { aver.= } \\
& \text { max.= }\end{array}$ & & $\begin{array}{l}3 \\
24.19 \\
30\end{array}$ & $\begin{array}{l}\text { Wald } \mathrm{chi}^{2}= \\
\text { Prob }>\mathrm{chi}^{2}=\end{array}$ & $\begin{array}{c}1673.16 \\
0.00\end{array}$ \\
\hline
\end{tabular}

Note: * Significant variable at $10 \% ;{ }^{* *}$ Significant variable at $5 \% ;{ }^{* * *}$ Significant variable at $1 \%$.

A second interesting observation we can make is that the value of the $\beta_{\text {oil }}$ coefficient is almost twice as large as the market return coefficient $\left(\beta_{m}\right)$. This observation contrasts with the result of Sadorsky (2001) who finds a market beta larger than a crude oil beta in each of his regressions. A possible explanation of this difference is that Sadorsky uses a sub-index whereas we use individual firms. Sadorsky's larger $\beta_{m}$ is therefore normal since the energy sub-index is an important component of the Canadian market portfolio. Not only do we find $\beta_{\mathrm{m}}<\beta_{\text {oil }}$, we also have $\beta_{\mathrm{m}}<1$, suggesting that energy firms are less risky than the Canadian market. This result contrasts with previous studies: Faff and Chan (1998) find a $\beta_{m}>1$ for the Australian gold sector, Kavussanos and Marcoulis (1997) find a large $\beta_{m}$ for American refineries, and Henriques and Sadorsky (2001) find a large $\beta_{\mathrm{m}}$ for Canadian paper and forest firms. On the other hand, Chua and al. (1990) does find that $\beta_{\mathrm{m}}<1$ for Australian gold companies.

The third interesting observation we can make based on Table 5 is that the exchange rate beta $\left(\beta_{\mathrm{er}}\right)$ is negative and close to one in absolute terms. This means that a depreciation of the Canadian dollar against the U.S. dollar leads, on average, to negative returns for Canadian oil and gas stocks. It is consistent with the results of Sadorsky (2001) but still surprising given that Canadian companies are net exporters of oil and gas to the United States, so that Canadian firms should normally benefit from a depreciation of the Canadian currency. Sadorsky's (2001) likely explanation is that a depreciation of the Canadian dollar increases the cost of importing drilling materials and the cost of financing. 


\subsection{Producers versus Integrated}

In Table 6, we present regression results for our sub-sample of producers (panel A) and of integrated firms (panel B). We note that the common factors have a different impact on the two subgroups. We note that the stock price return of oil and gas producers increases (Panel $A$ ) when the market return, the oil price return and the natural gas price return increase, and when the interest rate and the exchange rate returns decrease. Moreover all these return betas are significant at the one percent level or better.

In contrast to producers, only two factors are significant in explaining the return of integrated firms (panel B): The market return (at the $10 \%$ level) and the natural gas price return (at the $5 \%$ level). Moreover, the impacts of $\beta_{\mathrm{er}}$ and of $\beta_{\text {ir }}$ are inverted in each panel so that a rise in the exchange rate or a rise in the interest rate does not affect negatively the return of integrated oil and gas firms as they do in the case of producers.

\section{Table 6: Regressions of the five common factors: producers vs. integrated}

Results using the following equation:

$$
r_{i, t}=\alpha+\beta_{i r} r_{i r, t}+\beta_{e r} r_{e r, t}+\beta_{m} r_{m, t}+\beta_{\text {oil }} r_{\text {oil }, t}+\beta_{\text {gas }} r_{\text {gas }, t}+\varepsilon_{t}
$$

where $r_{i, t}$ is the excess return of each stock on the 1-month T-bill rate, $\alpha$ is the constant, $r_{i r, t}$ is the interest rate return, $r_{\text {er, }}$ is the exchange rate return, $r_{m, t}$ is the market excess return on the 1-month T-bill rate, $r_{\text {oil,t }}$ is the crude oil price return, $r_{\text {gas, }, t}$ is the natural gas price return and $\varepsilon_{\mathrm{t}}$ are residuals. All returns are on a quarterly basis and the timeframe is from March 1995 to September 2002. The equation is used twice: on the sample of producers (panel A) and on the sample of integrated (panel B). The econometric model is the GLS-Panel.

\begin{tabular}{|c|c|c|c|c|c|c|}
\hline \multicolumn{7}{|c|}{ Panel A : Producers } \\
\hline Variable & Const. & $\beta_{m}$ & $\beta_{\text {er }}$ & $\beta_{\text {ir }}$ & $\beta_{\text {oil }}$ & $\beta_{\text {gas }}$ \\
\hline $\begin{array}{l}\text { Coefficient } \\
\text { (Stand. dev.) }\end{array}$ & $\begin{array}{l}1.844^{\star \star \star} \\
(0.413)\end{array}$ & $\begin{array}{l}0.172^{* * *} \\
(0.044)\end{array}$ & $\begin{array}{c}-0.833^{\star \star \star} \\
(0.172)\end{array}$ & $\begin{array}{c}-0.051^{* * *} \\
(0.017)\end{array}$ & $\begin{array}{l}0.288^{* \star *} \\
(0.027)\end{array}$ & $\begin{array}{c}0.102^{* \star *} \\
(0.013)\end{array}$ \\
\hline $\begin{array}{ll}\text { Observations } & \\
\text { Panels } & =\end{array}$ & $\begin{array}{c}2008 \\
99\end{array}$ & $\begin{array}{l}\text { Observations } \\
\text { per panel }\end{array}$ & $\begin{array}{l}\min .= \\
\text { aver. }= \\
\max .=\end{array}$ & $\begin{array}{l}3 \\
23.82 \\
30\end{array}$ & $\begin{array}{l}\text { Wald } \mathrm{chi}^{2}= \\
\text { Prob }>\mathrm{chi}^{2}=\end{array}$ & $\begin{array}{c}320.23 \\
0.00\end{array}$ \\
\hline \multicolumn{7}{|c|}{ Panel B : Integrated } \\
\hline Variable & Const. & $\beta_{m}$ & $\beta_{\mathrm{er}}$ & $\beta_{\text {ir }}$ & $\beta_{\text {oil }}$ & $\beta_{\text {gas }}$ \\
\hline $\begin{array}{l}\text { Coefficient } \\
\text { (Stand. dev.) }\end{array}$ & $\begin{array}{c}0.353 \\
(1.528) \\
\end{array}$ & $\begin{array}{l}0.214^{*} \\
(0.119)\end{array}$ & $\begin{array}{c}0.193 \\
(0.453)\end{array}$ & $\begin{array}{c}0.002 \\
(0.035)\end{array}$ & $\begin{array}{c}0.122 \\
(0.076)\end{array}$ & $\begin{array}{l}0.084^{* *} \\
(0.036)\end{array}$ \\
\hline $\begin{array}{ll}\text { Observations } & \\
\text { Panels } & =\end{array}$ & $\begin{array}{c}158 \\
6\end{array}$ & $\begin{array}{l}\text { Observations } \\
\text { per panel }\end{array}$ & $\begin{array}{l}\min .= \\
\text { aver. }= \\
\text { max. }=\end{array}$ & $\begin{array}{l}8 \\
28.89 \\
30\end{array}$ & $\begin{array}{l}\text { Wald } \mathrm{chi}^{2}= \\
\text { Prob }>\mathrm{chi}^{2}=\end{array}$ & $\begin{array}{l}14.08 \\
0.02\end{array}$ \\
\hline
\end{tabular}

Note: * Significant variable at $10 \% ;{ }^{* *}$ Significant variable at $5 \% ;{ }^{* \star *}$ Significant variable at $1 \%$. 
Another result worth mentioning is that the oil price return and the natural gas return have a greater impact on producers than on integrated firms. Although this difference may not be significant, producers appear more affected by variations in oil and gas prices than integrated firms.

By pooling the two subgroups, Table 7 gives a better portrait of where the differences between them are. We control for integrated firms by including a dummy variable equal to 1 when the firm is integrated and zero when the firm is a producer. By using an interactive term of the common factor return with this dummy variable, we are able to assess how different is the impact of each common factor on integrated firms compared to producers. Table 7 shows that integrated firms are significantly positively affected by a depreciation of the Canadian dollar $\left(\beta_{1 \mathrm{er}}+\beta_{2 \mathrm{er}}\right)$ whereas producers are significantly negatively affected $\left(\beta_{1 \mathrm{er}}\right)$. Furthermore, crude oil prices have a significantly larger impact on producers $\left(\beta_{1 \text { oil }}\right)$ than on integrated companies $\left(\beta_{1 \mathrm{oil}}+\beta_{2 \mathrm{oil}}\right)$.

\section{Table 7: Regression with dummy variables: producers vs. integrated}

Results using the following equation:

$$
\begin{aligned}
& r_{i, t}=\alpha+\beta_{1 i r} r_{i r, t}+\beta_{1 e r} r_{e r, t}+\beta_{1 m} r_{m, t}+\beta_{1 \text { oil }} r_{\text {oil }, t}+\beta_{1 \text { gas }} r_{\text {gas }, t}+ \\
& D_{1} \beta_{2 i r} r_{i r, t}+D_{2} \beta_{2 e r} r_{e r, t}+D_{3} \beta_{2 m} r_{m, t}+D_{4} \beta_{2 \text { oil }} r_{\text {oil }, t}+D_{5} \beta_{2 \text { gas }} r_{\text {gas }, t}+\varepsilon_{t}
\end{aligned}
$$

where $\mathrm{r}_{\mathrm{i}, \mathrm{t}}$ is the excess return of each stock on the 1-month T-bill rate, $\alpha$ is the constant, $\mathrm{r}_{\mathrm{ir}, \mathrm{t}}$ is the interest rate return, $\mathrm{r}_{\mathrm{er}, \mathrm{t}}$ is the exchange rate return, $r_{m, t}$ is the market excess return on the 1-month T-bill rate, $r_{\text {oilt, }}$ is the crude oil price return, $r_{g a s, t}$ is the natural gas price return and $\varepsilon_{\mathrm{t}}$ are residuals. $\beta_{1}$ 's are betas related to the entire sample (producers and integrated) while $\beta_{2}$ 's are betas unique to integrated. More precisely, the coefficient of correlation for each common variable for producers is associated to $\beta_{1}$, while the one for integrated is the sum of $\beta_{1}$ and $\beta_{2}$. Dummy variables $\left(D_{1}, D_{2}, D_{3}, D_{4}, D_{5}\right)$

\begin{tabular}{|c|c|c|c|c|c|c|c|c|c|c|c|}
\hline Variable & Const. & $\beta_{1 \mathrm{~m}}$ & $\beta_{1 \mathrm{er}}$ & $\beta_{1 \mathrm{ir}}$ & $\beta_{1 \text { oil }}$ & $\beta_{1 \text { gas }}$ & $\beta_{2 m}$ & $\beta_{2 e r}$ & $\beta_{2 \text { ir }}$ & $\beta_{\text {2oil }}$ & $\beta_{2 \text { gas }}$ \\
\hline \multirow[t]{2}{*}{$\begin{array}{l}\text { Coefficient } \\
\text { (Stand. } \\
\text { Dev.) }\end{array}$} & $\begin{array}{c}1.527^{* * *} \\
(0.410)\end{array}$ & $\begin{array}{c}0.183^{* * *} \\
(0.045)\end{array}$ & $\begin{array}{c}-0.749^{* * *} \\
(0.179)\end{array}$ & $\begin{array}{c}-0.049^{* * *} \\
(0.017)\end{array}$ & $\begin{array}{c}0.292^{* * *} \\
(0.028)\end{array}$ & $\begin{array}{c}0.100^{* * *} \\
(0.013)\end{array}$ & $\begin{array}{c}0.054 \\
(0.119)\end{array}$ & $\begin{array}{l}0.911^{* *} \\
(0.472)\end{array}$ & $\begin{array}{c}0.052 \\
(0.038)\end{array}$ & $\begin{array}{c}- \\
0.179^{* *} \\
(0.077)\end{array}$ & $\begin{array}{l}-0.020 \\
(0.036)\end{array}$ \\
\hline & $\begin{array}{l}\text { Observ } \\
\text { Panels }\end{array}$ & $\begin{aligned} \text { ions } & = \\
& =\end{aligned}$ & $\begin{array}{c}2166 \\
105\end{array}$ & & $\begin{array}{l}\text { Observ } \\
\text { per } \\
\text { panel }\end{array}$ & $\begin{array}{r}\text { v. } \min .= \\
\text { aver. }= \\
\text { max. }=\end{array}$ & $\begin{array}{l}3 \\
24.19 \\
30\end{array}$ & \multicolumn{2}{|c|}{$\begin{array}{l}\text { Wald } \mathrm{chi}^{2}= \\
\text { Prob }>\mathrm{chi}^{2}=\end{array}$} & \multicolumn{2}{|c|}{$\begin{array}{c}319.28 \\
0.00\end{array}$} \\
\hline
\end{tabular}
are equal to 1 when the firm is integrated and 0 when the firm is a producer. The econometric model is the GLS-Panel.

Note: * Significant variable at $10 \% ;{ }^{* *}$ Significant variable at $5 \% ;{ }^{* * *}$ Significant variable at $1 \%$.

An explanation for these results is that producers a more willing to hedge their exposure to the different risks than integrated firms, similar to the results of Géczy and al. (1997), who showed that firm size is associated with a hedging demand of exchange rate risk, and of Haushalter (2000), who observed a similar pattern with respect to oil price risk. The fact that integrated firms are less exposed to oil prices risk (as measured by the sum $\beta_{1 \text { oil }}$ and $\beta_{2 \text { oil }}$ ) is likely explained by their vertical integration. 
To explain why integrated firms seem to benefit from a depreciation of the Canadian dollar whereas producers seem to be penalized, we must find what activities of integrated firms, apart from the oil and gas production, profit from a depreciation of the Canadian dollar. One such activity is refining. Indeed, Canadian refineries firms would obtain a cost advantage over American refineries following a weakening of the Canadian dollar. If integrated firms can distribute their products south of the border or prevent American firms from exporting to Canada, Canadian integrated firms that own refineries would benefit from a depreciation of the local currency.

Regarding the other three risk factors, $\beta_{2 m}, \beta_{2 \text { ir }}$ and $\beta_{2 g a s}$, their impact is not significantly different on producers than on integrated firms. Although the sign and the amplitude of each factor are consistent with the separate regressions of Table 6 (i.e., natural gas prices and interest rates have less impact, and market return has more impact on integrated firms than producers), the differences are not statistically different from zero.

\subsection{Oil versus gas}

We continue our comparative study in Table 8 by looking at the impact of the five common risk factors on firms producing mainly crude oil (panels $A$ and $C$ ) and on those focusing on natural gas (panels $B$ and D). We include in panel A (panel B) companies whose quarterly mean and median production of crude oil (natural gas) represents at least $60 \%$ of their total production volume. As highlighted by Rajan and Servaes (1997), this procedure leads to more distinct subgroups than a 50-50 split so that any conclusion that we draw should be more robust. In panel $C$ and $D$, we include firms whose quarterly production of crude oil (natural gas) fall into the $50 \%$ to $60 \%$ range of their total production volume.

Note in Table 8 that four coefficients are significant in panel $\mathrm{A}\left(\beta_{\mathrm{m}}, \beta_{\mathrm{ir}}, \beta_{\mathrm{oil}}, \beta_{\mathrm{gas}}\right)$, whereas only three are significant in panel $B$ (the same save $\beta_{\text {ir }}$ ). With the exception of $\beta_{\text {er }}$ in panel $B$, the signs of the coefficients in the first two panels are all coherent with the results obtained for the entire sample (see Table 5). Moreover, consistent with the fact that oil represents at least $60 \%$ of total volumes of production in panel $A$ and less than $40 \%$ in panel $B$, the difference between $\beta_{\text {oil }}$ and $\beta_{\text {gas }}$ is larger in panel $A$ than in panel $B$. 


\section{Table 8: Regressions of the five common factors: crude oil vs. natural gas}

Results using the following equation:

$$
r_{i, t}=\alpha+\beta_{i r} r_{i r, t}+\beta_{e r} r_{e r, t}+\beta_{m} r_{m, t}+\beta_{\text {oil }} r_{\text {oil }, t}+\beta_{\text {gas }} r_{\text {gas }, t}+\varepsilon_{t}
$$

where $r_{i, t}$ is the excess return of each stock on the 1-month T-bill rate, $\alpha$ is the constant, $r_{i r, t}$ is the interest rate return, $r_{e r, t}$ is the exchange rate return, $r_{m, t}$ is the market excess return on the 1-month T-bill rate, $r_{\text {oill, }}$ is the crude oil price return, $r_{\text {gas, },}$ is the natural gas price return and $\varepsilon_{t}$ are residuals. All returns are on a quarterly basis and the timeframe is from March 1995 to September 2002. The equation is used twice: on the sample of firms mainly producing crude oil (panel $A$ ) and on the sample of companies mainly producing natural gas (panel B). The econometric model is the GLS-Panel.

\begin{tabular}{|c|c|c|c|c|c|c|}
\hline \multicolumn{7}{|c|}{ Panel A : crude oil $\geq 60 \%$} \\
\hline Variable & Const. & $\beta_{\mathrm{m}}$ & $\beta_{\mathrm{er}}$ & 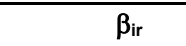 & $\beta_{\text {oil }}$ & $\beta_{\text {gas }}$ \\
\hline $\begin{array}{l}\text { Coefficient } \\
\text { (Stand. dev.) }\end{array}$ & $\begin{array}{l}-0.174 \\
(0.886)\end{array}$ & $\begin{array}{c}0.219^{* \star *} \\
(0.072)\end{array}$ & $\begin{array}{l}-0.356 \\
(0.291)\end{array}$ & $\begin{array}{l}-0.043^{*} \\
(0.023)\end{array}$ & $\begin{array}{c}0.312^{* * *} \\
(0.044)\end{array}$ & $\begin{array}{c}0.079^{\star \star \star} \\
(0.021)\end{array}$ \\
\hline $\begin{array}{ll}\text { Observations } & = \\
\text { Panels } & =\end{array}$ & $\begin{array}{c}878 \\
42\end{array}$ & $\begin{array}{l}\text { Observations } \\
\text { per panel }\end{array}$ & $\begin{array}{l}\min .= \\
\text { aver. }= \\
\max .=\end{array}$ & $\begin{array}{l}4 \\
20.90 \\
30 \\
\end{array}$ & $\begin{array}{l}\text { Wald } \mathrm{chi}^{2}= \\
\text { Prob }>\mathrm{chi}^{2}=\end{array}$ & $\begin{array}{c}95.90 \\
0.00\end{array}$ \\
\hline \multicolumn{7}{|c|}{ Panel B : natural gas $\geq 60 \%$} \\
\hline Variable & Const. & 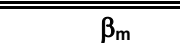 & $\begin{array}{c}\beta_{\text {er }} \\
\end{array}$ & 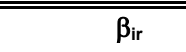 & $\beta_{\text {oil }}$ & $\beta_{\text {gas }}$ \\
\hline $\begin{array}{l}\text { Coefficient } \\
\text { (Stand. dev.) }\end{array}$ & $\begin{array}{l}2.802^{\star *} \\
(1.172)\end{array}$ & $\begin{array}{c}0.461^{* \star *} \\
(0.119)\end{array}$ & $\begin{array}{c}0.307 \\
(0.541) \\
\end{array}$ & $\begin{array}{l}-0.046 \\
(0.045) \\
\end{array}$ & $\begin{array}{c}0.215^{\star \star *} \\
(0.073)\end{array}$ & $\begin{array}{c}0.160^{* * \star} \\
(0.036)\end{array}$ \\
\hline $\begin{array}{ll}\text { Observations } & = \\
\text { Panels } & =\end{array}$ & $\begin{array}{c}461 \\
21\end{array}$ & $\begin{array}{l}\text { Observations } \\
\text { per panel }\end{array}$ & $\begin{array}{l}\min .= \\
\text { aver.= } \\
\text { max.= }\end{array}$ & $\begin{array}{l}7 \\
21.95 \\
30 \\
\end{array}$ & $\begin{array}{l}\text { Wald } \mathrm{chi}^{2}= \\
\text { Prob }>\mathrm{chi}^{2}=\end{array}$ & $\begin{array}{l}55.08 \\
0.00\end{array}$ \\
\hline \multicolumn{7}{|c|}{ Panel C : crude oil $50-60 \%$} \\
\hline Variable & Const. & 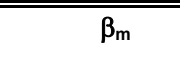 & $\beta_{\text {er }}$ & $\bar{\beta} \beta_{\text {ir }}$ & $\beta_{\text {oil }}$ & $\beta_{\text {gas }}$ \\
\hline $\begin{array}{l}\text { Coefficient } \\
\text { (Stand. dev.) }\end{array}$ & $\begin{array}{l}-1.305^{\star} \\
(0.778)\end{array}$ & $\begin{array}{c}0.272^{* * *} \\
(0.084)\end{array}$ & $\begin{array}{l}-0.168 \\
(0.350) \\
\end{array}$ & $\begin{array}{l}-0.002 \\
(0.027) \\
\end{array}$ & $\begin{array}{c}0.330^{* * *} \\
(0.050)\end{array}$ & $\begin{array}{c}0.068^{\star \star \star} \\
(0.026)\end{array}$ \\
\hline $\begin{array}{ll}\text { Observations } & = \\
\text { Panels } & =\end{array}$ & $\begin{array}{c}300 \\
15\end{array}$ & $\begin{array}{l}\text { Observations } \\
\text { per panel }\end{array}$ & $\begin{array}{l}\min .= \\
\text { aver. }= \\
\text { max. }=\end{array}$ & $\begin{array}{l}5 \\
20.00 \\
30 \\
\end{array}$ & $\begin{array}{l}\text { Wald } \mathrm{chi}^{2}= \\
\text { Prob }>\mathrm{chi}^{2}=\end{array}$ & $\begin{array}{c}85.50 \\
0.00\end{array}$ \\
\hline \multicolumn{7}{|c|}{ 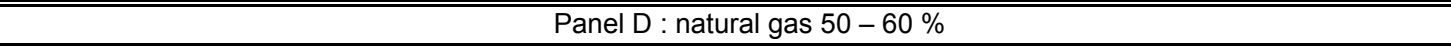 } \\
\hline Variable & Const. & 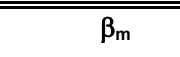 & $\beta_{\mathrm{er}}$ & 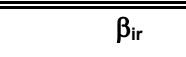 & $\beta_{\text {oil }}$ & $\beta_{\text {gas }}$ \\
\hline $\begin{array}{l}\text { Coefficient } \\
\text { (Stand. dev.) }\end{array}$ & $\begin{array}{c}0.683 \\
(1.113) \\
\end{array}$ & $\begin{array}{l}0.241^{* *} \\
(0.084)\end{array}$ & $\begin{array}{c}0.086 \\
(0.525) \\
\end{array}$ & $\begin{array}{l}-0.128^{* *} \\
(0.056)\end{array}$ & $\begin{array}{c}0.222^{* \star *} \\
(0.072)\end{array}$ & $\begin{array}{l}0.077^{* *} \\
(0.035)\end{array}$ \\
\hline $\begin{array}{l}\text { Observations }= \\
\text { Panels }=\end{array}$ & $\begin{array}{c}286 \\
16\end{array}$ & $\begin{array}{l}\text { Observations } \\
\text { per panel }\end{array}$ & $\begin{array}{l}\min .= \\
\text { aver. }= \\
\text { max. }=\end{array}$ & $\begin{array}{l}3 \\
17.88 \\
30\end{array}$ & $\begin{array}{l}\text { Wald } \mathrm{chi}^{2}= \\
\text { Prob }>\mathrm{chi}^{2}=\end{array}$ & $\begin{array}{c}40.75 \\
0.00\end{array}$ \\
\hline
\end{tabular}

Note: * Significant variable at $10 \% ;{ }^{* \star}$ Significant variable at $5 \% ;{ }^{* \star *}$ Significant variable at $1 \%$.

In panel $B$, we see that the stock return sensitivity of firms to a variation in oil prices is higher than to gas prices (i.e., $\beta_{\text {oil }}>\beta_{\text {gas }}$ ). Even though oil represents less than $40 \%$ of their production, oil prices may be so much higher than gas prices (8.1 times higher on average between Q1 1995 and Q4 2002 to be exact) that the revenue of gas-intensive firms remains more sensible to oil prices than to natural gas prices. Put differently, the price effect of oil is greater that the volume effect of gas. Another possible explanation (Haushalter, 2000) is that natural gas producers use more hedging instruments. 
Comparing the $\beta_{m}$ 's in panels $A$ and $B$, we see that the impact of the market return is not the same on crude oil intensive firms as on natural gas intensive firms. In fact, the sensitivity of natural gas firms is twice as large as that of crude oil firms. This results is made clearer in Table 9, where we include a dummy equal to 1 when the firm is focused primarily on natural gas (the panel A firms in Table 8) and zero when the firm is focused on crude oil (the panel B firms in Table 8). This dummy variable is then interacted with the common factor returns to highlight the differences between the two subgroups.

\section{Table 9: Regression with dummy variables: crude oil $\geq 60 \%$ vs. natural gas $\geq 60 \%$}

Results using the following equation:

$$
\begin{aligned}
& r_{i, t}=\alpha+\beta_{1 i r} r_{i r, t}+\beta_{1 e r} r_{e r, t}+\beta_{1 m} r_{m, t}+\beta_{1 \text { oil }} r_{\text {oil }, t}+\beta_{1 \text { gas }} r_{\text {gas }, t}+ \\
& D_{1} \beta_{2 i r} r_{i r, t}+D_{2} \beta_{2 e r} r_{e r, t}+D_{3} \beta_{2 m} r_{m, t}+D_{4} \beta_{2 \text { oil }} r_{\text {oil }, t}+D_{5} \beta_{2 \text { gas }} r_{\text {gas }, t}+\varepsilon_{t}
\end{aligned}
$$

where $r_{i, t}$ is the excess return of each stock on the 1-month T-bill rate, $\alpha$ is the constant, $r_{\text {ir, }}$ is the interest rate return, $r_{\text {er, }}$ is the exchange rate return, $r_{m, t}$ is the market excess return on the 1-month T-bill rate, $r_{\text {oilt, }}$ is the crude oil price return, $r_{\text {gas, },}$ is the natural gas price return and $\varepsilon_{\mathrm{t}}$ are residuals. $\beta_{1}$ 's are betas related to the entire sample (firms mainly producing crude oil and firms mainly producing natural gas) while $\beta_{2}$ 's are betas unique to companies focusing on the production of natural gas. More precisely, the coefficient of correlation oil for each macroeconomic variable for firms mainly producing crude oil is associated to $\beta_{1}$, while for firms mainly producing natural gas, it is the sum of $\beta_{1}$ and $\beta_{2}$. Dummy variables $\left(D_{1}, D_{2}, D_{3}\right.$, $D_{4}, D_{5}$ ) are equal to 1 when the firm is focusing on natural gas and 0 when the firm is focusing on crude oil. The

\begin{tabular}{|c|c|c|c|c|c|c|c|c|c|c|c|}
\hline Variable & Const. & $\beta_{1 \mathrm{~m}}$ & $\beta_{1 \mathrm{er}}$ & $\beta_{1 \mathrm{ir}}$ & $\beta_{1 \mathrm{oil}}$ & $\beta_{1 \text { gas }}$ & $\beta_{2 m}$ & $\beta_{2 \text { er }}$ & $\beta_{2 \text { ir }}$ & $\beta_{\text {2oil }}$ & $\beta_{2 \text { gas }}$ \\
\hline $\begin{array}{l}\text { Coefficient } \\
\text { (Stand. } \\
\text { Dev.) }\end{array}$ & $\begin{array}{c}0.905 \\
(0.706)\end{array}$ & $\begin{array}{c}0.232^{* * *} \\
(0.072)\end{array}$ & $\begin{array}{l}-0.366 \\
(0.289)\end{array}$ & $\begin{array}{l}-0.040^{*} \\
(0.023)\end{array}$ & $\begin{array}{c}0.308^{* * *} \\
(0.044)\end{array}$ & $\begin{array}{c}0.075^{* \star *} \\
(0.021)\end{array}$ & $\begin{array}{c}0.207 \\
(0.138)\end{array}$ & $\begin{array}{c}0.764 \\
(0.614)\end{array}$ & $\begin{array}{l}-0.013 \\
(0.051)\end{array}$ & $\begin{array}{l}-0.078 \\
(0.085)\end{array}$ & $\begin{array}{l}0.096^{\star \star} \\
(0.041)\end{array}$ \\
\hline $\begin{array}{l}\text { Observations } \\
\text { Panels }\end{array}$ & $=$ & $\begin{array}{c}1339 \\
63\end{array}$ & & $\begin{array}{l}\text { Obs } \\
\text { per } \\
\text { pan }\end{array}$ & $\begin{array}{r}\text { rv. } \min .= \\
\text { aver. }= \\
\text { max. }=\end{array}$ & & $\begin{array}{l}4 \\
21.25 \\
30\end{array}$ & & $\begin{array}{l}\text { Wald } \mathrm{chi}^{2}= \\
\text { Prob }>\mathrm{chi}^{2}=\end{array}$ & & $\begin{array}{c}152.34 \\
0.00\end{array}$ \\
\hline
\end{tabular}
econometric model is the GLS-Panel.

Note: ${ }^{*}$ Significant variable at $10 \% ;{ }^{* \star}$ Significant variable at $5 \% ;{ }^{* \star *}$ Significant variable at $1 \%$.

We see in Table 9 that $\beta_{2 m}$ is significantly larger than $\beta_{1 m}$ (more than twice as large to be exact), suggesting that natural gas intensive firms are twice as sensible to stock market variations as oil intensive firms. The characteristics of the two subgroups explain part of this difference. One such characteristic is that, in term of production volume, operational cash flows, proven reserves and revenues (see Table A2 in the paper's appendix), natural gas intensive firms are relatively smaller than crude oil firms. We know from previous work by Chan and al. (1985) and Chan and Chen (1988) that the market risk premium is, in general, larger for smaller firms. As a result, the $\beta_{\mathrm{m}}$ of (small) natural gas intensive firms is logically larger than for (large) crude oil intensive firms. 
The last two panels of Table 8 focus on firms that have a more balanced production: Crude oil represents between $50 \%$ and $60 \%$ of total production for firms in Panel C, and between $40 \%$ and $50 \%$ for firms in Panel $D$. We see in panel $C$ that three coefficients are significant $\left(\beta_{\mathrm{m}}, \beta_{\mathrm{oil}}, \beta_{\mathrm{gas}}\right)$ whereas four are significant in panel $\mathrm{D}$ (the same plus $\beta_{\mathrm{ir}}$ ). Even if panel $\mathrm{C}$ includes two integrated and panel $\mathrm{A}$ includes four integrated firms, the magnitude and the sign of the coefficients are similar. Moreover, even if Panel $\mathrm{C}$ firms are on average larger (see Table A2 in the appendix), we find no size effect, contrary to our previous discussion.

Although the regression results of panels $A$ and $C$ provides no significant difference in the impact of the common risk factors, the results are radically different when comparing the results of panels $D$ and $B$. For instance, the coefficients $\beta_{m}$ and $\beta_{\text {gas }}$ are significantly larger in the case of highly natural gas intensive firms (panel B) than in the case of slightly natural gas intensive firms (panel D). More precisely, the impact of natural gas price volatility on a firm's stock price is twice as high if natural gas represents more than $60 \%$ of the firm's production volume.

In all four panels of Table $8, \beta_{\mathrm{er}}$ is never significant. Although the difference is not significant, a depreciation of the Canadian dollar appears to benefit natural gas producers more than crude oil producers. A possible reason comes from the shear export value of each commodity. For 2001, Statistics Canada reports that crude oil export equaled 15.4 billions \$CAN whereas natural gas exports totalized 25.6 billions \$CAN, so that the base of depreciation in larger for natural gas exports than crude oil exports.

\subsection{Years $1995-1998$ vs. $2000-2002$}

Our next analysis tests for the presence of a structural change in natural gas and oil prices over time. As depicted in Figure 1, oil and natural gas prices behaved differently depending on the sub-period: From 1995 to 1998 oil prices had a downward trend and the price of natural gas hovered around 2.50 \$US whereas from 1999 onward, oil prices trended upward and natural gas prices jumped above 3.00 \$US. Given this situation, Table 10 presents the regression results using the five common factors for the two time 
periods: $1995-1998$ in panel A and 2000-2002 in panel B. We omitted the year 1999 so that the two periods are clearly separated.

In panel $A$ of Table 10, we observe that market return and crude oil prices had a positive and significant impact on Canadian oil and gas stock returns for the 1995-1998 time period. The other three determinants do not have a significant influence, however, although the signs are the same as the results presented in Table 5. Panel B (years 2000-2002) shows that four determinants have a significant effect on stock returns.

Table 10: Regression of the five common factors: 1995-1998 vs. 2000-2002

Results using the following equation:

$$
r_{i, t}=\alpha+\beta_{i r} r_{i r, t}+\beta_{e r} r_{e r, t}+\beta_{m} r_{m, t}+\beta_{\text {oil }} r_{\text {oil }, t}+\beta_{\text {gas }} r_{\text {gas }, t}+\varepsilon_{t}
$$

where $r_{i, t}$ is the excess return of each stock on the 1-month T-bill rate, $\alpha$ is the constant, $r_{i r, t}$ is the interest rate return, $r_{e r, t}$ is the exchange rate return, $r_{m, t}$ is the market excess return on the 1-month T-bill rate, $r_{\text {oilt, }}$ is the crude oil price return, $r_{\text {gas, }, t}$ is the natural gas price return and $\varepsilon_{\mathrm{t}}$ are residuals. All returns are on a quarterly basis and the timeframe is from March 1995 to September 2002. The equation is used twice: for the period 1995-1998 (panel A) and for the period 2000-2002 (panel B). The econometric model is the GLS-Panel.

\begin{tabular}{|c|c|c|c|c|c|c|}
\hline \multicolumn{7}{|c|}{ Panel A : 1995-1998 } \\
\hline Variable & Const. & $\beta_{\mathrm{m}}$ & $\begin{array}{ll} & \beta_{\mathrm{er}}\end{array}$ & $\beta_{\text {ir }}$ & $\beta_{\text {oil }}$ & $\beta_{\text {gas }}$ \\
\hline $\begin{array}{l}\text { Coefficient } \\
\text { (Stand. dev.) }\end{array}$ & $\begin{array}{c}0.789 \\
(0.584)\end{array}$ & $\begin{array}{l}0.534^{\star * *} \\
(0.059)\end{array}$ & $\begin{array}{l}-0.279 \\
(0.297)\end{array}$ & $\begin{array}{l}-0.055 \\
(0.040)\end{array}$ & $\begin{array}{l}0.373^{* * *} \\
(0.049)\end{array}$ & $\begin{array}{c}0.013 \\
(0.019) \\
\end{array}$ \\
\hline $\begin{array}{ll}\text { Observations } & = \\
\text { Panels } & =\end{array}$ & $\begin{array}{c}1285 \\
103\end{array}$ & $\begin{array}{l}\text { Observations } \\
\text { per panel }\end{array}$ & $\begin{array}{l}\min .= \\
\text { aver.= } \\
\max .=\end{array}$ & $\begin{array}{l}2 \\
13.67 \\
15\end{array}$ & $\begin{array}{l}\text { Wald } \mathrm{chi}^{2}= \\
\text { Prob }>\text { chi }^{2}=\end{array}$ & $\begin{array}{c}277.58 \\
0.00\end{array}$ \\
\hline \multicolumn{7}{|c|}{ Panel B : 2000-2002 } \\
\hline Variable & Const. & $\beta_{\mathrm{m}}$ & $\beta_{\mathrm{er}}$ & $\beta_{\text {ir }}$ & $\beta_{\text {oil }}$ & $\beta_{\text {gas }}$ \\
\hline $\begin{array}{l}\text { Coefficient } \\
\text { (Stand. dev.) }\end{array}$ & $\begin{array}{c}2.566^{\star \star \star} \\
(0.485)\end{array}$ & $\begin{array}{l}0.271^{* * *} \\
(0.044)\end{array}$ & $\begin{array}{c}0.710^{\star \star \star} \\
(0.262)\end{array}$ & $\begin{array}{l}-0.005 \\
(0.020)\end{array}$ & $\begin{array}{c}0.392^{\star * *} \\
(0.048)\end{array}$ & $\begin{array}{l}0.09^{* \star *} \\
(0.014)\end{array}$ \\
\hline $\begin{array}{ll}\text { Observations } & = \\
\text { Panels } & =\end{array}$ & $\begin{array}{c}561 \\
68\end{array}$ & $\begin{array}{l}\text { Observations } \\
\text { per panel }\end{array}$ & $\begin{array}{l}\min .= \\
\text { aver.= } \\
\text { max. }=\end{array}$ & $\begin{array}{l}2 \\
9.47 \\
11\end{array}$ & $\begin{array}{l}\text { Wald } \mathrm{chi}^{2}= \\
\text { Prob }>\mathrm{chi}^{2}=\end{array}$ & $\begin{array}{c}550.73 \\
0.00\end{array}$ \\
\hline
\end{tabular}

Note: * Significant variable at $10 \% ;{ }^{* \star}$ Significant variable at $5 \%$; ${ }^{* * \star}$ Significant variable at $1 \%$.

No structural change is seen for crude oil prices, as $\beta_{\text {oil }}$ is almost equal in the two panels. We observe, on the other hand, a structural change in the case of natural gas, exchange rate and market return. The impact of the price of natural gas and of the exchange rate in panel $B$ are positive and statistically different than in panel $A$. The value of $\beta_{m}$ in panel $B$ is half the value as in panel $A$. Table 11 confirms these observations.

In Table 11 we validate that the anticipated structural change for crude oil prices does not materialize. $\beta_{20 i l}$, which represents the different impact that oil prices have in the two periods, is small and non-significant. Although there does not appear to be a structural 
shift in the impact of crude oil, three other shifts are apparent: Natural gas $\left(\beta_{2 \text { gas }}\right.$ is positive and significant), exchange rate $\left(\beta_{2 \mathrm{er}}>0\right)$ and market return $\left(\beta_{2 \mathrm{~m}}<0\right)$.

Table 11: Regression with dummy variables: 1995-1998 vs. 2000-2002

Results using the following equation:

$$
\begin{aligned}
& r_{i, t}=\alpha+\beta_{1 i r} r_{i r, t}+\beta_{1 e r} r_{e r, t}+\beta_{1 m} r_{m, t}+\beta_{1 \text { oil }} r_{\text {oil }, t}+\beta_{1 \text { gas }} r_{\text {gas }, t}+ \\
& D_{1} \beta_{2 i r} r_{i r, t}+D_{2} \beta_{2 e r} r_{e r, t}+D_{3} \beta_{2 m} r_{m, t}+D_{4} \beta_{2 \text { oil }} r_{\text {oil }, t}+D_{5} \beta_{2 \text { gas }} r_{\text {gas }, t}+\varepsilon_{t}
\end{aligned}
$$

where $r_{i, t}$ is the excess return of each stock on the 1-month T-bill rate, $\alpha$ is the constant, $r_{i r, t}$ is the interest rate return, $r_{\text {er, }}$ is the exchange rate return, $r_{m, t}$ is the market excess return on the 1-month T-bill rate, $r_{\text {oil,t }}$ is the crude oil price return, $r_{\text {gas }, t}$ is the natural gas price return and $\varepsilon_{t}$ are residuals. $\beta_{1}$ 's are betas related to the entire sample (period of 1995-1998 and period of 2000-2002) while $\beta_{2}$ 's are betas unique to the period of 2000-2002. More precisely, the coefficient of correlation for each common variable for the period 1995-1998 is associated to $\beta_{1}$, while for the period 2000-2002, it is the sum of $\beta_{1}$ and $\beta_{2}$. Dummy variables $\left(D_{1}, D_{2}, D_{3}, D_{4}, D_{5}\right)$ are equal to 1 when the period is $2000-2002$ and 0 when the period is 1995-

\begin{tabular}{|c|c|c|c|c|c|c|c|c|c|c|c|}
\hline Variable & Const. & $\beta_{1 \mathrm{~m}}$ & $\beta_{1 \mathrm{er}}$ & $\beta_{1 \mathrm{ir}}$ & $\beta_{1 \text { oil }}$ & $\beta_{1 \text { gas }}$ & $\beta_{2 m}$ & $\beta_{2 e r}$ & $\beta_{2 \text { ir }}$ & $\beta_{\text {2oil }}$ & $\beta_{2 \text { gas }}$ \\
\hline $\begin{array}{l}\text { Coefficient } \\
\text { (Stand. } \\
\text { Dev.) }\end{array}$ & $\begin{array}{l}1.075^{\star *} \\
(0.497)\end{array}$ & $\begin{array}{l}0.538^{\star \star *} \\
(0.060)\end{array}$ & $\begin{array}{l}-0.539^{*} \\
(0.300)\end{array}$ & $\begin{array}{l}-0.049 \\
(0.040)\end{array}$ & $\begin{array}{l}0.348^{\star \star *} \\
(0.049)\end{array}$ & $\begin{array}{c}0.014 \\
(0.020)\end{array}$ & $\begin{array}{c}-0.375^{\star \star \star *} \\
(0.093)\end{array}$ & $\begin{array}{l}1.097^{* *} \\
(0.430)\end{array}$ & $\begin{array}{c}0.041 \\
(0.049)\end{array}$ & $\begin{array}{c}0.008 \\
(0.105)\end{array}$ & $\begin{array}{c}0.068^{* * *} \\
(0.026)\end{array}$ \\
\hline $\begin{array}{l}\text { Observations } \\
\text { Panels }\end{array}$ & $\begin{array}{l}= \\
=\end{array}$ & $\begin{array}{c}1854 \\
105\end{array}$ & & $\begin{array}{l}\text { Observ } \\
\text { per } \\
\text { panel }\end{array}$ & $\begin{array}{l}\min .= \\
\text { aver. }= \\
\max .=\end{array}$ & & $\begin{array}{l}3 \\
17.66 \\
26\end{array}$ & & $\begin{array}{l}\text { Wald } \mathrm{chi}^{2}= \\
\text { Prob }>\text { chi }^{2}=\end{array}$ & & $\begin{array}{c}343.68 \\
0.00\end{array}$ \\
\hline
\end{tabular}
1998. The econometric model is the GLS-Panel.

Note: * Significant variable at $10 \% ;{ }^{* *}$ Significant variable at $5 \% ;{ }^{* * *}$ Significant variable at $1 \%$.

Looking at these results, we believe that the large swing that we observe in the value of the exchange rate beta might come from two factors. First, we conjecture that Canadian energy firms might have reduced their imports of machinery and their financing in U.S. dollars following the sustained depreciation of the Canadian dollar. Furthermore, for their drilling and exploration requirements, they might have purchased their equipment from Canadian firms instead of American firms. As a result, anticipating the depreciation of the Canadian dollar, ${ }^{9}$ Canadian oil and gas firms probably tried to increase their exports of oil and gas while lowering their imports of drilling equipment.

Second, we observe a consolidation of the oil and gas sector in the second period. More precisely, we conjecture that, because a vast majority of firms in 2000-2002 were awash with cash and were looking to stabilize production and growth for the coming years, a drop of the Canadian dollar might have stimulated acquisitions by American firms. As opposed to the period of 1995-1998, commodity prices were high in 2000-2002 so that a depreciation of the Canadian dollar made acquisitions relatively cheap for American companies. As many as 15 sample firms were acquired during this period. This dynamic can explain why we find a positive coefficient for the exchange rate for 2000-2002. 
Concerning the market return coefficient, the result is consequent with the opposite trends of Canadian oil and gas stocks and the stock market in the second period. Looking at Figure 2, we see that the value of the energy sub index (S\&P/TSX Energy Index) shows an upper trend during the years 2000-2002. Helped by a favorable commodity prices environment, the energy sub-index shows six quarterly returns above $5 \%$ and only two quarterly returns below $-1 \%$ during these four years. On the opposite, the TSE 300 is more volatile while the market index fluctuates in negative and positive territory during the years 2000-2002.

Figure 2: S\&P/TSX Energy and TSE 300 quarterly returns (in \%)

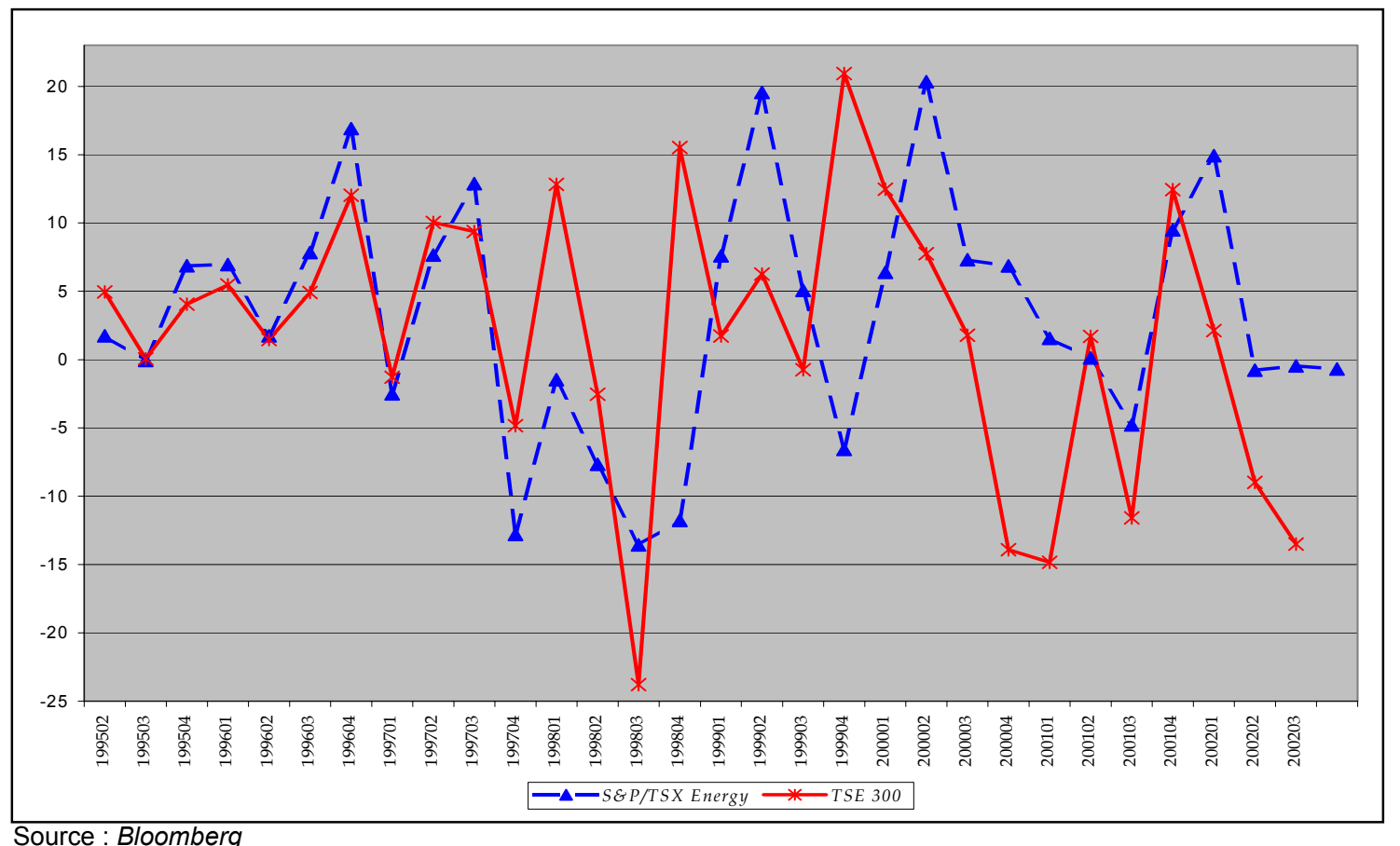

Moreover, this situation of disparity did not happened in the previous years. Visibly, the two indexes move more closely from 1995 to 1998. Consequently, it appears logical that the market beta is affected by this situation and that we observe a structural change for the latter coefficient.

\footnotetext{
${ }^{9}$ The depreciation of the Canadian dollar continued in $2000-2002$.
} 


\subsection{Fundamental factors analysis}

In the previous section, we studied the impact of common economic factors. Here, we present the results of our model using fundamental determinants. Table 13 shows that three on these fundamental factors are significant in explaining the return of energy stocks. It appears that changes in operational cash flows, proven reserves and the volume of production had a significant impact on the stock return of oil and gas firms: The first two (cash flows and proven reserves) are positive, and the third is negative.

\section{Table 13: Regression of the five common and fundamental factors on the complete sample}

$$
\begin{aligned}
& r_{i, t}=\alpha+\beta_{i r} r_{i r, t}+\beta_{e r} r_{e r, t}+\beta_{m} r_{m, t}+\beta_{\text {oil }} r_{o i l, t}+\beta_{\text {gas }} r_{g a s, t}+\beta_{d r i} r_{d r i, i, t-1} \\
& +\beta_{c f} r_{c f, i, t-1}+D_{1} \beta_{\text {res }} r_{\text {res }, i, t-1}+\beta_{\text {prod }} r_{\text {prod }, i, t-1}+\beta_{\text {debt }} r_{\text {debt }, i, t-1}+\varepsilon_{t}
\end{aligned}
$$

where $r_{\mathrm{i}, \mathrm{t}}$ is the excess return of each stock on the 1-month T-bill rate, $\alpha$ is the constant, $\mathrm{r}_{\mathrm{dr}, \mathrm{i}, \mathrm{t}-1}$ is the variation of the drilling success, $r_{c f, i, t-1}$ is the variation of cash flows, $r_{\text {res, }, \mathrm{it}-1}$ is the variation of proved reverses, $r_{\text {prod, i,t-1 }}$ is the variation of volumes of production, $r_{\text {dette, it }-1}$ is the variation of debt and $\varepsilon_{t}$ are residuals. The $r_{i r}, r_{e r}, r_{m}, r_{\text {oil }}$ et $r_{\text {gas }}$ are the returns related to the five common factors previously defined. $D_{1}$ is a dummy variable equal to 0 in the first three quarters and equal to 1 in the fourth. All returns are on a quarterly basis, except for the variation of proved reserves, which is on a yearly basis. The

\begin{tabular}{|c|c|c|c|c|c|c|c|c|c|c|c|}
\hline Variable & Const. & $\beta_{m}$ & $\beta_{\mathrm{er}}$ & $\beta_{\text {ir }}$ & $\beta_{\text {oil }}$ & $\beta_{\text {gas }}$ & $\beta_{\text {dri }}$ & $\beta_{\mathrm{cf}}$ & $\beta_{\text {res }}$ & $\beta_{\text {prod }}$ & $\beta_{\text {debt }}$ \\
\hline $\begin{array}{l}\text { Coefficient } \\
\text { (Stand. } \\
\text { Dev.) }\end{array}$ & $\begin{array}{c}-1.060^{\star *} \\
(0.475)\end{array}$ & $\begin{array}{l}0.107^{* *} \\
(0.053)\end{array}$ & $\begin{array}{l}-0.013 \\
(0.265)\end{array}$ & $\begin{array}{l}-0.028^{*} \\
(0.015)\end{array}$ & $\begin{array}{c}0.334^{* * *} \\
(0.030)\end{array}$ & $\begin{array}{c}0.085^{* * *} \\
(0.015)\end{array}$ & $\begin{array}{c}0.019 \\
(0.019)\end{array}$ & $\begin{array}{l}0.010^{* *} \\
(0.005)\end{array}$ & $\begin{array}{l}0.060^{* *} \\
(0.031)\end{array}$ & $\begin{array}{c}-0.027^{* * *} \\
(0.006)\end{array}$ & $\begin{array}{c}0.000 \\
(0.000)\end{array}$ \\
\hline $\begin{array}{l}\text { Observations } \\
\text { Panels }\end{array}$ & $\begin{array}{l}= \\
=\end{array}$ & $\begin{array}{c}935 \\
90\end{array}$ & & $\begin{array}{l}\text { Observ. } \\
\text { per } \\
\text { panel }\end{array}$ & $\begin{array}{l}\min .= \\
\text { aver. }= \\
\text { max. }=\end{array}$ & $\begin{array}{l}2 \\
13 \\
28 \\
\end{array}$ & & \multicolumn{2}{|c|}{$\begin{array}{l}\text { Wald } \mathrm{chi}^{2}= \\
\text { Prob }>\text { chi }^{2}=\end{array}$} & \multicolumn{2}{|r|}{$\begin{array}{c}263.11 \\
0.00\end{array}$} \\
\hline
\end{tabular}
timeframe is from March 1995 to September 2002. The econometric model is the GLS-Panel.

Note: ${ }^{*}$ Significant variable at $10 \% ;{ }^{* *}$ Significant variable at $5 \% ;{ }^{* \star *}$ Significant variable at $1 \%$.

The cash flow and proven reserve coefficients are consequent with the perception that operational cash flows are an important and relatively cheap source of financing (see Mayer and Frank, 1985). In addition, the use of internal cash flows offers more financial flexibility, lowers financial risk, and allows firms to invest in new developments and to acquire other companies. As for proven reserves, they likely reduce operational risk, allow production increases and lead to an appreciation of the firm's assets.

At the opposite, the sign of $\beta_{\text {prod }}$ is surprising. Indeed, our anticipation, that an increase in production should be beneficial for a firm since it increases its revenue, is not supported in the results. $\beta_{\text {prod }}$ is significantly negative and robust to a single-factor regression (see Table A3 in the appendix). A possible explanation is that the returns related to the production of crude oil and of natural gas is concave so that energy firms experience 
decreasing returns of scale. The second reason is that, because the cost associated with the shutdown of a well is very large ${ }^{10}$ energy firms continue to produce, even if the average cost is superior to the average benefit. A third possibility is that increased production is a signal that many firms are pumping out of the same oil patch, leading to a so-called "tragedy of the commons." As a result oil and gas producers, acting in their own self-interest, generate lower industry profits than if they collaborated. A final possibility is that more production is associated with the exercising of an option of the possibility to drill proven reserve patches. By exercising this option, firms reduce the risk of their assets and thus their required stock return.

\section{Conclusion}

Our purpose with this paper was to determine what explained the total return of oil and gas stocks in Canada. Our approach was premised on the fact that macroeconomic factors common to all firms as well as firm specific factors should explain these total returns. A particularity of the oil and gas firms is that most of their value is driven by the price of the commodity they produce, a price upon which no firm has any impact.

Our main contributions to the literature are two-fold. First we included natural gas prices and industry specific factors to explain the stock return of oil and gas firms. Second, we examined how the factors affect differently producers and integrated firms, and how differently they affect crude oil intensive versus natural gas intensive firms. As a result, we are able to document the incidence of five common factors (interest rates, Canadian exchange rate with the U.S. dollar, market return, oil prices, and natural gas prices) and five fundamental factors (proven reserves, volume of production, debt level, operational cash flows, and drilling success) on the stock return of oil and gas corporations.

We also analyzed how these returns depended on the price environments and on the operational decisions of oil and gas firms. In the first case, we were able to identify a structural change that resulted from an important shift in natural gas and crude oil prices. In the second case, we show that the stock return determinants of integrated energy

\footnotetext{
${ }^{10}$ For example, the cost of a production shutdown at Suncor during Q2-2003 was approximately 100 millions dollars.
} 
companies are different than those of independent producers. Similarly, determinants are not the same for firms producing mainly oil and for firms focusing on natural gas.

An interesting implication that one draws from the research presented in this paper is that, in contrast to Kavussanos and Marcoulis (1997) for American refineries, the market beta of Canadian oil and gas firms is smaller than one. This result suggests that the systematic market risk of energy firms is smaller than that of the average Canadian corporation. This result holds for both time periods, and for integrated energy companies as well as oil and gas producers.

One surprising result that we found is that firms that increase their production of crude oil and/or of natural gas experience a lower stock return on the market. This result is surprising considering that more production should increase the firm's available cash flows. A possible explanation comes from the theory of real options (see Luerhman, 1998, and Copeland and Antikarov, 2001, Boyer et al., 2004). This theory stipulates that firms hold a portfolio of options on the assets of the firm to expand production (or reduce it). These options are exercised whenever the value of the underlying asset is sufficiently high. When these options are exercised, the risk of the firm is reduced because an option on the assets is always riskier than the asset itself. For our paper, it is quite possible that an increase in production signifies that the firm has exercised its options so that risk is reduced and return should be reduced as well.

The final point we want to make in these concluding remarks is that the approach we used to examine the stock return of Canadian oil and gas firms offers interesting insights into hedging practices that one could use to isolate a particular risk. For instance, we find that the USD/CAD exchange rate does not behave as we first expected, so that even if Canada is a net exporter of oil and gas, it is probably a net importer of oil and gas machinery. As such, it appears that the price of the imported machinery fluctuates more with the exchange rate than does the price of exported oil. 


\section{References}

Abeysekera, S. and A. Mahajan (1987). A Test of the APT in Pricing Canadian Stocks. Canadian Journal of Administrative Sciences, 4: 186-198.

Aleisa, E., S. Dibooglu and D. Hammoudeh (2003). Relationships among U.S. Oil Prices and Oil Industry Equity Indices. International Review of Economics \& Finance, 15: 1-29.

Boyer, M., P. Christoffersen, P. Lasserre and A. Pavlov (2004). Value Creation, Risk Management and Real Options. Journal of Management Research, 3:42-62

Chan, K.C. and N. Chen (1988). An Unconditional Asset-Pricing Test and the Role of Firm Size as an Instrumental Variable for Risk. Journal of Finance, 43: 309-325.

Chan, K.C., N. Chen and D. A. Hsieh (1985). An Exploratory Investigation of the Firm Size Effect. Journal of Financial Economics, 14: 451-471.

Chen, N. (1991). Financial Investment Opportunities and the Macroeconomy. Journal of Finance, 46: 529-554.

Chen, N., R. Roll, R. and S. A. Ross (1986). Economic Forces and the Stock Market. Journal of Business, 59: 383-403.

Chua, J. H., G. Sick and R. S. Woodward (1990) Diversifying with Gold Stocks. Financial Analysts Journal, July-August: 76-79.

Copeland, T. and V. Antikarov (2001). Real Options: A Practitionner's Guide. Texere, New York, New York.

Faff, R. and T. Brailsford (1999). Oil Price Risk and the Australian Stock Market. Journal of Energy, Finance and Development, 4: 69-87.

Faff, R. and H. Chan (1998). A Multifactor Model of Gold Industry Stock Returns: Evidence from Australian Equity Market. Applied Financial Economics, 8: 21-28.

Fama, E. and K. French (1989). Business Conditions and Expected Returns on Stock and Bonds. Journal of Financial Economics, 25: 23-49.

Fama,E., and K. French (1992). The Cross-section of Expected Returns. Journal of Finance, 47: 427-465.

Fama, E. and K. French (1993). Common Risk Factors in the Returns on Stock and Bonds. Journal of Financial Economics, 33: 3-56.

Ferson, W. E. and C. R. Harvey (1991). The Variation of Economic Risk Premiums. Journal of Political Economy, 99: 385-415.

Géczy, C., B. Minton and C. Schrand (1997). Why Firms Use Currency Derivatives. Journal of Finance, 52: 1332-1354. 
Haushalter, G. D. (2000). Financing Policy, Basis Risk, and Corporate Hedging: Evidence from Oil and Gas Producers. Journal of Finance, 55: 107-152.

Henriques, I. and P. Sadorsky (2001). Multifactor Risk and the Stock Returns of Canadian Paper and Forest Products Companies. Forest Policy and Economics, 3: 199208.

Hughes, P. (1984). A Test of Arbitrage Pricing Theory using Canadian Security Returns. Canadian Journal of Administrative Sciences, 1: 195-214.

Jensen, M. C. (1986). Agency Costs of Free Cash Flow, Corporate Finance and Takeovers. American Economic Review, 76: 323-339.

Johansen, S. (1988). Statistical Analysis of Cointegration Vectors. Journal of Economics Dynamic \& Control, 12: 231-254.

Jones, C. M. and G. Kaul (1996). Oil and the Stock Markets. Journal of Finance, 51 : 463-491.

Jorion, P., and E. Schwartz (1986). Integration vs. Segmentation in the Canadian Stock Market. Journal of Finance, 41: 603-614.

Kairkkainen, P. (1997). Oil and Gas, in the Handbook of Canadian security analysis, John Wiley \& Sons Canada, 1997, Pages 141-180.

Kavussanos, M. G. and S. N. Marcoulis (1997). The Stock Market Perception of Industry Risk and Microeconomic Factors: the Case of the US Water Transportation Industry Versus Other Transport Industries. ", Transportation Research Part E: Logistics and Transportation Review, 33: 147-158.

Keim, D. and R. Stambaugh (1986). Predicting Returns in the Stock and Bond Markets. Journal of Financial Economics, 17: 357-390.

Khoo, A. (1994). Estimation of Foreign Exchange Exposure: an Application to Mining Companies in Australia. Journal of International Money and Finance, 13: 342-363.

Koutoulas, G. and L. Kryzanowski (1994). Integration or Segmentation of the Canadian Stock Market: Evidence Based on the APT. Canadian Journal of Economics, 27: 329351.

Kryzanowski, L. and M. C. To (1983). General Factor Models and the Structure of Security Returns. Journal of Financial and Quantitative Analysis, 18 : 31-52.

Lafrance, R. and S. Van Norden (1995). Les Déterminants Fondamentaux du Taux de Change et le Dollar Canadien. Revue de la Banque du Canada, Spring 1995 : 17-33.

Luehrman, T. A. (1998). Investment Opportunities as Real Options: Getting Started on the Numbers. Harvard Business Review.

McDonald, J. G. and B. H. Solnick (1977). Valuation and Strategy for Gold Stocks. Journal of Portfolio Management, 4: 29-33. 
Merton, R. C. (1973). An Intertemporal Capital Asset Pricing Model. Econometrica, 41: 867-887.

Mittoo, U. R. (1992). Additional Evidence on Integration in the Canadian Stock Market. Journal of Finance, 47: 2035-2054.

Morin, R. A. (1980). Market Line Theory and the Canadian Equity Market. Journal of Business Administration, Fall: 57-76.

Myers, S. C. (1977). Determinants of Corporate Borrowing. Journal of Financial Economics, 5: 147-175.

Rajan, R. and H. Servaes (1997). Analysts Following of Initial Public Offering. Journal of Finance, 52: 507-529.

Sadorsky, P. (1999). Oil Price Shocks and Stock Market Activity. Energy Economics, 21: 449-469.

Sadorsky, P. (2001). Risk Factors in Stock Returns of Canadian Oil and Gas Companies. Energy Economics, 23: 17-28.

Sadorsky, P. (2000). The Empirical Relationship between Energy Futures Prices and Exchange Rates. Energy Economics, 22: 253-266.

Sadorsky, P. (2002). Time-varying Risk Premium in Petroleum Futures Prices. Energy Economics, 24: 539-556.

Sharpe, W. F. (1964). Capital Asset Prices: A Theory of Market Equilibrium under Conditions of Risk. Journal of Finance, 19: 425-442.

Stulz, R. (1990). Managerial Discretion and Optimal Financing Policies. Journal of Financial Economics, 26: 3-27.

Wooldridge, J. (2002). Econometric Analysis of Cross Section and Panel Data, MIT Press, 752 Pages. 


\section{Appendix}

Table A1: List of the firms

\begin{tabular}{|c|c|c|c|c|c|c|c|c|}
\hline & Company name & Types & & Company name & Types & & Company name & Types \\
\hline 1 & Alberta Energy & Producers & 36 & $\begin{array}{l}\text { Hurricane } \\
\text { Hydrocarbons }\end{array}$ & Integrated & 71 & Poco Petroleums & Producers \\
\hline 2 & Amber Enery & Producers & 37 & Husky Energy & Integrated & 72 & Probe Exploration & Producers \\
\hline 3 & Anderson Exploration & Producers & 38 & Imperial Oil Ltd & Integrated & 73 & Purcell Energy & Producers \\
\hline 4 & Atcor Resources & Producers & 39 & Intensity Resources & Producers & 74 & Ranger Oil & Producers \\
\hline 5 & Avid Oil \& Gas & Producers & 40 & $\begin{array}{l}\text { International Colin } \\
\text { Energy }\end{array}$ & Producers & 75 & Real Resources & Producers \\
\hline 6 & Barrington Petroleum & Producers & 41 & Inverness Petroleum & Producers & 76 & Remington Energy & Producers \\
\hline 7 & Baytex Energy & Producers & 42 & Ionic Petroleum & Producers & 77 & $\begin{array}{l}\text { Renaissance } \\
\text { Energy }\end{array}$ & Producers \\
\hline 8 & $\begin{array}{l}\text { Beau Canada } \\
\text { Exploration }\end{array}$ & Producers & 43 & Jordan Petroleum & Producers & 78 & Renata Resources & Producers \\
\hline 9 & Bellator Exploration & Producers & 44 & Ketch Energy & Producers & 79 & Resolute Energy & Producers \\
\hline 10 & Berkley Petroleum & Producers & 45 & Key West Energy & Producers & 80 & Richland Petroleum & Producers \\
\hline 11 & Blue Range Resource & Producers & 46 & Magin Energy & Producers & 81 & Rigel Energy & Producers \\
\hline 12 & Bonavista Petroleum & Producers & 47 & Mark Resources & Producers & 82 & $\begin{array}{l}\text { Rio Alto } \\
\text { Exploration }\end{array}$ & Producers \\
\hline 13 & Cabre Exploration & Producers & 48 & Maxx Petroleum & Producers & 83 & Sceptre Resources & Producers \\
\hline 14 & Canadian 88 Energy & Producers & 49 & Meota Resources & Producers & 84 & Search Energy & Producers \\
\hline 15 & $\begin{array}{l}\text { Canadian Hunter } \\
\text { Exploration }\end{array}$ & Producers & 50 & Merit Energy & Producers & 85 & Serenpet & Producers \\
\hline 16 & $\begin{array}{l}\text { Canadian Natural } \\
\text { Resources }\end{array}$ & Producers & 51 & Morgan Hydrocarbons & Producers & 86 & Shell Canada & Integrated \\
\hline 17 & Cimarron Petroleum & Producers & 52 & Navigo Energy & Producers & 87 & Southward Energy & Producers \\
\hline 18 & Compton Petroleum & Producers & 53 & Newport Petroleum & Producers & 88 & $\begin{array}{l}\text { Stampeder } \\
\text { Exploration }\end{array}$ & Producers \\
\hline 19 & Courage Energy & Producers & 54 & Nexen & Producers & 89 & Storm Energy & Producers \\
\hline 20 & Crestar Energy & Producers & 55 & Niko Resources & Producers & 90 & Summit Resources & Producers \\
\hline 21 & CS Resources & Producers & 56 & $\begin{array}{l}\text { Norcen Energy } \\
\text { Resources }\end{array}$ & Producers & 91 & Suncor & Integrated \\
\hline 22 & Cypress Energy & Producers & 57 & Northrock Resources & Producers & 92 & Talisman Energy & Producers \\
\hline 23 & Danoil Energy & Producers & 58 & Northstar Energy & Producers & 93 & Tarragon Oil \& Gas & Producers \\
\hline 24 & Dorset Exploration & Producers & 59 & Numac Energy & Producers & 94 & Tethys Energy & Producers \\
\hline 25 & Edge Energy & Producers & 60 & Olympia Energy & Producers & 95 & Thunder Energy & Producers \\
\hline 26 & Elan Energy & Producers & 61 & Pacalta Resources & Producers & 96 & $\begin{array}{l}\text { TransAtlantic } \\
\text { Petroleum }\end{array}$ & Producers \\
\hline 27 & Elk Point Resources & Producers & 62 & Paramount Resources & Producers & 97 & Transwest Energy & Producers \\
\hline 28 & Encal Energy & Producers & 63 & Penn West Petroleum & Producers & 98 & Tri Link Resources & Producers \\
\hline 29 & Encana & Producers & 64 & Petro Canada & Integrated & 99 & Triumph Energy & Producers \\
\hline 30 & Founders Energy & Producers & 65 & $\begin{array}{l}\text { Petrobank Energy } \\
\text { Resources }\end{array}$ & Producers & 100 & Ulster Petroleum & Producers \\
\hline 31 & Gardiner Oil \& Gas & Producers & 66 & Petromet Resources & Producers & 101 & Upton Resources & Producers \\
\hline 32 & Genesis Exploration & Producers & 67 & Petrorep Resources & Producers & 102 & Velvet Exploration & Producers \\
\hline 33 & Grad \& Walker Energy & Producers & 68 & Peyto Exploration & Producers & 103 & $\begin{array}{l}\text { Vermilion } \\
\text { Resources }\end{array}$ & Producers \\
\hline 34 & $\begin{array}{l}\text { Gulf Canada } \\
\text { Resources }\end{array}$ & Producers & 69 & Pinnacle Resources & Producers & 104 & Wascana Energy & Producers \\
\hline 35 & HCO Energy & Producers & 70 & Player Petroleum & Producers & 105 & Zargon Oil \& Gas & Producers \\
\hline
\end{tabular}

In bold are the integrated firms. 
Table A2: Comparative data concerning the size of firms focusing on crude oil production and firms focusing on natural gas production

\begin{tabular}{|c|c|c|c|c|}
\hline Observations & $\begin{array}{c}\text { Crude oil } \\
\text { production } \geq \\
60 \%\end{array}$ & $\begin{array}{l}\text { Crude oil } \\
\text { production } \\
50 \%-60 \%\end{array}$ & $\begin{array}{c}\text { Natural gas } \\
\text { production } \geq \\
60 \%\end{array}$ & $\begin{array}{l}\text { Natural gas } \\
\text { production } \\
50 \%-60 \%\end{array}$ \\
\hline $\begin{array}{l}\text { Quarterly volumes of } \\
\text { production (boe): } \\
\begin{aligned}- & \text { mean } \\
- & \text { median }\end{aligned}\end{array}$ & $\begin{array}{c}14728254 \\
1770980\end{array}$ & $\begin{array}{c}16574471 \\
8845284\end{array}$ & $\begin{array}{l}3715354 \\
1265480\end{array}$ & $\begin{array}{l}3268118 \\
1409085\end{array}$ \\
\hline $\begin{array}{l}\text { Proved } \text { reserves (boe) } \\
\begin{aligned}: & \text { mean } \\
- & \text { median }\end{aligned}\end{array}$ & $\begin{array}{c}240599084 \\
21960000\end{array}$ & $\begin{array}{l}273479072 \\
114397050\end{array}$ & $\begin{array}{l}50310843 \\
18834200\end{array}$ & $\begin{array}{l}44345200 \\
19625000\end{array}$ \\
\hline 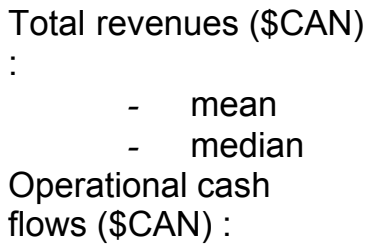 & $\begin{array}{c}654940573 \\
31192292\end{array}$ & $\begin{array}{c}1030339208 \\
149358000\end{array}$ & $\begin{array}{l}82832910 \\
23653000\end{array}$ & $\begin{array}{l}56840347 \\
26170000\end{array}$ \\
\hline $\begin{array}{ll}\text { - } & \text { mean } \\
\text { - } & \text { median }\end{array}$ & $\begin{array}{c}178822477 \\
16793681 \\
\end{array}$ & $\begin{array}{c}258732965 \\
88018000\end{array}$ & $\begin{array}{l}56704231 \\
14763000\end{array}$ & $\begin{array}{l}34392677 \\
15514000\end{array}$ \\
\hline
\end{tabular}

Table A3: Single-factor regression (production volume)

\begin{tabular}{|c|c|c|c|c|c|}
\hline Variable & Const. & $\beta_{\text {prod }}$ & & & \\
\hline $\begin{array}{l}\text { Coefficient } \\
\text { (Stand. dev.) }\end{array}$ & $\begin{array}{c}2.354^{\star \star \star} \\
(0.395)\end{array}$ & $\begin{array}{c}-0.015^{\star \star \star} \\
(0.005)\end{array}$ & & & \\
\hline $\begin{array}{l}\text { Observations } \\
\text { Panels }\end{array}$ & $\begin{array}{c}1737 \\
104\end{array}$ & $\begin{array}{ll}\text { Observations } & \text { min. }= \\
\text { Per panel } & \text { aver.= } \\
& \text { max.= }\end{array}$ & $\begin{array}{l}2 \\
20.79 \\
29\end{array}$ & $\begin{array}{l}\text { Wald } \mathrm{chi}^{2}= \\
\text { Prob }>\mathrm{chi}^{2}=\end{array}$ & $\begin{array}{c}11.40 \\
0.00\end{array}$ \\
\hline
\end{tabular}

